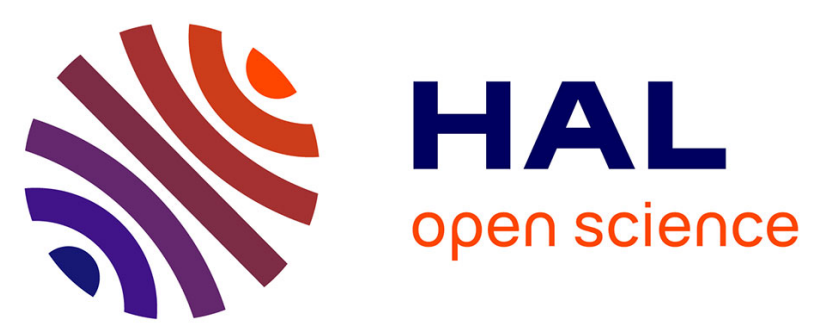

\title{
Anthropogenic-Biogenic Interactions at Night: Enhanced Formation of Secondary Aerosols and Particulate Nitrogen- and Sulfur-Containing Organics from beta-Pinene Oxidation
}

Li Xu, Zhaomin Yang, Narcisse Tsona, Xinke Wang, Christian George, Lin Du

\section{To cite this version:}

Li Xu, Zhaomin Yang, Narcisse Tsona, Xinke Wang, Christian George, et al.. Anthropogenic-Biogenic Interactions at Night: Enhanced Formation of Secondary Aerosols and Particulate Nitrogen- and Sulfur-Containing Organics from beta-Pinene Oxidation. Environmental Science and Technology, 2021, 55 (12), pp.7794-7807. 10.1021/acs.est.0c07879 . hal-03300495

\section{HAL Id: hal-03300495 \\ https://hal.science/hal-03300495}

Submitted on 6 Oct 2021

HAL is a multi-disciplinary open access archive for the deposit and dissemination of scientific research documents, whether they are published or not. The documents may come from teaching and research institutions in France or abroad, or from public or private research centers.
L'archive ouverte pluridisciplinaire HAL, est destinée au dépôt et à la diffusion de documents scientifiques de niveau recherche, publiés ou non, émanant des établissements d'enseignement et de recherche français ou étrangers, des laboratoires publics ou privés. 


\title{
Anthropogenic-Biogenic Interactions at Night: Enhanced Formation of Secondary Aerosols and Particulate Nitrogen- and Sulfur-Containing Organics from $\beta$-Pinene Oxidation
}

\author{
Li Xu, Zhaomin Yang, Narcisse T. Tsona, Xinke Wang, Christian George, and Lin Du*
}

\begin{abstract}
The oxidative photo-dehydrogenation of glycerol to produce $\mathrm{H} 2$ and other valuable chemicals was studied using different materials. In particular, Pt nanoparticles were deposited on microemulsion-synthesized TiO2 via surface organometallic chemistry (SOMC) and compared with photocatalysts obtained using more conventional methods. Welldefined $\mathrm{Pt}(\mathrm{II})$ single-site titania-grafted were prepared reacting the surface hydroxyl groups of TiO2 nano-oxides with the organometallic Pt(COD)Me2 complex. Sample reduction under H2 generated ultrafine Pt nanoparticles well-dispersed on titania surface. Its performance under simulated solar light showed superior activity when compared to analogous Ptcontaining catalysts prepared by other methods. Improved dispersion of Pt metal on titania surface was among the primary reasons of a better overall activity, providing relatively high rates of hydrogen productivity. Moreover, an increase of glyceraldehyde productivity in liquid phase was observed with the increase of Pt dispersion, demonstrating that the metal dispersion can strongly affect the selectivity of chemicals produced in the reaction. Comparison with state of the art shows that the present material exhibits excellent performance for a combined positive effect of the high specific surface area of titania prepared by microemulsion, giving access to the increased densities of active sites and the high dispersion of $\mathrm{Pt}$ nanoparticles given by the SOMC technique.
\end{abstract}

KEYWORDS: $\beta$-pinene, secondary aerosol, anthropogenic-biogenic interactions, organic nitrates, nitrooxy organosulfates, night time ozonolysis

\section{INTRODUCTION}

Aerosol particles in the atmosphere have negative impacts on regional air quality, climate change, and human health. ${ }^{1,2}$ Secondary aerosols produced during the oxidation of volatile organic compounds (VOCs) or inorganic precursors, for example, $\mathrm{NO}_{x} / \mathrm{SO}_{2} / \mathrm{NH}_{3}$, represent a large fraction of the total aerosol particle mass. ${ }^{3,4}$ Biogenic VOCs (BVOCs) are globally the main precursors for the secondary organic aerosol (SOA) budget due to their relatively high emission rates (about ten times higher than anthropogenic VOCs) and high reactivity toward atmospheric major oxidants. ${ }^{5-7}$ When BVOCs mix with anthropogenic emissions, the oxidation of BVOCs and their SOA formation potential can be altered as highlighted by many field observations. ${ }^{8-12}$ However, anthropogenic-biogenic interactions during SOA formation are more complex than their current representation in models, and consequently, uncertainties in the predicted SOA budget might be induced. $^{13-16}$
Nitrogen-containing and sulfur-containing compounds derived from BVOCs are key species in biogenic SOA. They can form via anthropogenic-biogenic interactions as anthropogenic pollutants, for example, $\mathrm{NO}_{x} / \mathrm{SO}_{2} / \mathrm{NH}_{3} /$ sulfate can serve as precursors to their formation. ${ }^{17-19} \mathrm{NO}_{x}$ may impact organic nitrates and total SOA formation by either influencing the local oxidation capacity, especially during night time through the $\mathrm{NO}_{3}$ radicals or by facilitating the formation of condensable organic nitrates. ${ }^{20-22}$ Modeled or field-observed correlations between $\mathrm{NO}_{x}$ and biogenic SOA formation are however still elusive as the decrease in $\mathrm{NO}_{x}$ can either decrease or increase biogenic SOA formation. ${ }^{23}$ Particulate organosulfates, which are usually formed through the reactions involving VOC oxidation products and acidic sulfate, could be a potential source of "missing SOA" that is not yet implemented in current atmospheric models. ${ }^{24,25}$ Indeed, 
Table 1. Summary of Experimental Conditions

\begin{tabular}{|c|c|c|c|c|c|c|c|c|c|}
\hline exp. no. ${ }^{a}$ & {$[\beta \text {-pinene }]_{0}(\mathrm{ppb})$} & {$\left[\mathrm{O}_{3}\right]_{0}(\mathrm{ppb})$} & {$\left[\mathrm{NO}_{2}\right]_{0}(\mathrm{ppb})$} & {$\left[\mathrm{SO}_{2}\right]_{0}(\mathrm{ppb})$} & {$\left[\mathrm{NH}_{3}\right]_{0}(\mathrm{ppb})$} & $T(\mathrm{~K})$ & $\mathrm{RH}(\%)$ & aerosol mass $\left(\mu \mathrm{g} \mathrm{m}^{-3}\right)$ & aerosol yield \\
\hline$\beta \mathrm{O}^{b}$ & 154 & 624 & 0 & & & 300 & 22 & $156.4 \pm 2.9$ & $0.18 \pm 0.01$ \\
\hline$\beta$ ON.1 & 154 & 567 & 32 & & & 298 & 33 & $290.8 \pm 12.4$ & $0.33 \pm 0.01$ \\
\hline$\beta \mathrm{ON} .2$ & 154 & 575 & 78 & & & 298 & 37 & $524.4 \pm 13.5$ & $0.60 \pm 0.03$ \\
\hline$\beta \mathrm{ON} .3$ & 154 & 606 & 116 & & & 299 & 29 & $711.3 \pm 18.6$ & $0.82 \pm 0.05$ \\
\hline$\beta \mathrm{ON} .4^{b}$ & 154 & 596 & 141 & & & 299 & 29 & $762.3 \pm 20.6$ & $0.87 \pm 0.05$ \\
\hline$\beta$ ON.5 & 156 & 564 & 347 & & & 300 & 31 & $1088.7 \pm 27.0$ & $1.25 \pm 0.07$ \\
\hline$\beta$ OS.1 & 156 & 543 & & 39 & & 297 & 31 & $281.8 \pm 6.2$ & $0.32 \pm 0.02$ \\
\hline$\beta \mathrm{OS} .2$ & 155 & 606 & & 59 & & 296 & 31 & $313.0 \pm 13.1$ & $0.36 \pm 0.02$ \\
\hline$\beta$ OS.3 & 156 & 614 & & 100 & & 297 & 30 & $415.5 \pm 6.5$ & $0.48 \pm 0.02$ \\
\hline$\beta \mathrm{OS} .4^{b}$ & 156 & 608 & & 134 & & 298 & 28 & $659.8 \pm 10.7$ & $0.76 \pm 0.04$ \\
\hline$\beta \mathrm{OS} .5$ & 157 & 612 & & 198 & & 299 & 25 & $676.4 \pm 10.7$ & $0.78 \pm 0.04$ \\
\hline$\beta$ OA.1 & 152 & 599 & & & 48 & 296 & 25 & $186.4 \pm 13.2$ & $0.21 \pm 0.02$ \\
\hline$\beta \mathrm{OA} .2^{b}$ & 155 & 591 & & & 98 & 297 & 29 & $178.4 \pm 5.4$ & $0.20 \pm 0.01$ \\
\hline$\beta$ OA.3 & 156 & 609 & & & 147 & 297 & 27 & $205.6 \pm 13.1$ & $0.24 \pm 0.01$ \\
\hline$\beta$ OA.4 & 156 & 591 & & & 196 & 296 & 28 & $214.3 \pm 5.0$ & $0.25 \pm 0.01$ \\
\hline$\beta$ ONS.1 & 155 & 615 & 78 & 104 & & 297 & 25 & $597.0 \pm 17.0$ & $0.68 \pm 0.04$ \\
\hline$\beta \mathrm{ONS} .2^{b}$ & 154 & 602 & 134 & 102 & & 297 & 31 & $795.5 \pm 10.0$ & $0.91 \pm 0.05$ \\
\hline$\beta$ OSA.1 & 156 & 550 & & 103 & 49 & 296 & 30 & $437.1 \pm 7.1$ & $0.50 \pm 0.03$ \\
\hline$\beta$ OSA. $2^{b}$ & 155 & 631 & & 105 & 98 & 295 & 22 & $375.6 \pm 2.3$ & $0.43 \pm 0.02$ \\
\hline$\beta$ OSA.3 & 151 & 551 & & 108 & 190 & 297 & 29 & $323.5 \pm 11.8$ & $0.37 \pm 0.02$ \\
\hline
\end{tabular}

${ }^{a}$ Abbreviations in experimental codes represent the reactants introduced into the chamber; that is, " $\beta$ " represents $\beta$-pinene, "O" represents ozone, "N" represents nitrogen dioxide, "S" represents sulfur dioxide, and "A" represents ammonia. The number represents experiments with the same reactants but different concentrations. ${ }^{b}$ Experiments were repeated under comparable conditions (Table S2 in the Supporting Information) to collect aerosol particles for offline composition analysis by UPLC/Q-Exactive-Focus HRMS.

BVOC-derived organosulfates have been widely observed from clean to polluted regions. ${ }^{8,10,17,24,26,27}$ Nitrooxy organosulfates (NOSs), the formation of which is related to both $\mathrm{NO}_{x}$ and sulfates, could also be produced with some diurnal trends. While daytime photooxidation was proposed to be the dominant source of biogenic NOSs in south China and northwest Europe, the enhanced NOS formation at night in Beijing and northeastern Germany was attributed to $\mathrm{NO}_{3}$ and sulfate chemistry. ${ }^{24,26-29}$ Understanding the precursors and formation pathways of these nitrogen- and sulfur-containing products not only requires field observations but also more laboratory experiments exploring BVOC oxidation and aerosol composition under various mixed conditions.

$\mathrm{O}_{3}$ and $\mathrm{NO}_{3}$ radicals are two main atmospheric oxidants at night and their relative dominance depends on the $\mathrm{NO}_{x}$ levels. ${ }^{30}$ In contrast to "traditional" studies where biogenic SOA formation from either $\mathrm{O}_{3}$ or $\mathrm{NO}_{3}$ was investigated separately, some recent studies directly explored those processes in the presence of $\mathrm{O}_{x}\left(\mathrm{O}_{3}+\mathrm{NO}_{2}\right)$. Different effects of $\mathrm{NO}_{2}$ have been characterized for different precursors as increasing $\mathrm{NO}_{2}$ decreased $\alpha$-pinene SOA yield but increased $\beta$ pinene, limonene, and $\gamma$-terpinene SOA formation. ${ }^{31-34}$ Sulfates usually act as seeds to alter the SOA mass and composition. ${ }^{35-37}$ Some studies directly introduced $\mathrm{SO}_{2}$ during BVOCs ozonolysis and showed that $\mathrm{SO}_{2}$ enhanced limonene and $\alpha$-cedrene SOA but had a minor effect on $\alpha$ pinene SOA. ${ }^{38,39}$ Whether enhanced functionalization could compensate for the reduced oligomerization likely determines the $\mathrm{SO}_{2}$ effects on final SOA yields. ${ }^{38}$

$\mathrm{NH}_{3}$ is another gaseous inorganic pollutant that has been observed to correlate well with the peak level of secondary particle pollution. ${ }^{40,41}$ Laboratory studies showed that $\mathrm{NH}_{3}$ tended to enhance SOA mass yield of $\alpha$-pinene and limonene ozonolysis by forming nitrogen-containing compounds, but no clear associations of $\mathrm{NH}_{3}$ with isoprene SOA were observed. $^{42-46}$ It has been predicted that $50 \%$ reduction in $\mathrm{NH}_{3}$ together with a $15 \%$ reduction in $\mathrm{NO}_{x}$ and $\mathrm{SO}_{2}$ could result in a decrease of particulate matter by $11-17 \%$ in China. ${ }^{47}$ While increasing attention has been paid to the synergistic effects of $\mathrm{NH}_{3}$ with $\mathrm{SO}_{2}$ or with $\mathrm{NO}_{2}$ in the photooxidation of some anthropogenic VOCs, such interactions in biogenic particle formation should be further investigated. ${ }^{48-31}$

$\beta$-pinene with a global annual emission rate of $18.9 \mathrm{Tg}$ contributes to about $17 \%$ of monoterpene in the atmosphere. ${ }^{7,52}$ Its atmospheric abundance and exocyclic double bond make it a common representative of exocyclic monoterpenes. ${ }^{53}$ The ozonolysis of $\beta$-pinene at night has been observed to have a significant contribution to nocturnal nucleation. ${ }^{54,55}$ In the present study, laboratory experiments were conducted to explore the effects of inorganic pollutants on aerosol formation initiated by nucleation during $\beta$-pinene ozonolysis in the absence of seed particles. First, we characterized particle formation when one single gas $\left(\mathrm{NO}_{2}\right.$, $\mathrm{SO}_{2}$, or $\left.\mathrm{NH}_{3}\right)$ and its mixtures $\left(\mathrm{NO}_{2}\right.$ and $\mathrm{SO}_{2}$ or $\mathrm{SO}_{2}$ and $\mathrm{NH}_{3}$ ) were present in the reaction system. Then, the chemical compositions of $\beta$-pinene SOA formed under different conditions were analyzed by infrared spectroscopy and highresolution mass spectrometry. Accordingly, formation pathways of the specific particulate products, including nitrogenand sulfur-containing compounds, were proposed to further reveal the effects of $\mathrm{NO}_{2}, \mathrm{SO}_{2}$, and $\mathrm{NH}_{3}$ on aerosol composition.

\section{EXPERIMENTAL METHODS}

2.1. Controlled Chamber Experiments. Aerosol particle formation during $\beta$-pinene ozonolysis under various conditions was studied in a $1 \mathrm{~m}^{3}$ Teflon chamber, which was suspended in a stainless-steel enclosure that enables dark conditions. Before the start of each experiment, the chamber was flushed with 
purified, dried air until the background particle concentrations were lower than $10 \mathrm{~cm}^{-3}$. Six groups of experiments were designed (Table 1). One group was pure $\beta$-pinene ozonolysis that was denoted as $\beta \mathrm{O}$ experiments. The other five groups that were performed with the presence of $\mathrm{NO}_{2}, \mathrm{SO}_{2}, \mathrm{NH}_{3}$, and the coexistence of $\mathrm{NO}_{2}$ and $\mathrm{SO}_{2}, \mathrm{SO}_{2}$ and $\mathrm{NH}_{3}$ were coded as $\beta \mathrm{ON}, \beta \mathrm{OS}, \beta \mathrm{OA}, \beta \mathrm{ONS}$, and $\beta \mathrm{OSA}$, respectively. The concentrations of $\beta$-pinene and $\mathrm{O}_{3}$ in the experiments were higher than those in the real atmosphere to keep the particle production significant enough for accurate measurements while ratios of inorganic gases $\left(\mathrm{NO}_{2}, \mathrm{SO}_{2}, \mathrm{NH}_{3}\right)$ to $\mathrm{O}_{3}$ and to $\beta$-pinene were in the range of $0-0.6$ and $0-2.2$, respectively. These ratios can partly represent relatively clean to relatively polluted atmospheric conditions, making comparisons between experimental conditions informative to aerosol generation in the atmosphere suffering different degrees of anthropogenicbiogenic interactions. ${ }^{15,55-62}$

Experiments were carried out in three consecutive steps. The first step was the introduction of reactants into the chamber. First, $\beta$-pinene (Aladdin, >99\%) and cyclohexane (Aladdin, $>99 \%)$ with a concentration ratio of 1:220 were evaporated into the chamber by a flow of zero air. With such an excessive amount of cyclohexane, more than $95 \%$ of $\mathrm{OH}$ radicals formed from $\beta$-pinene ozonolysis were expected to be scavenged, giving the rate constants of $\mathrm{OH}$ reactions with $\beta$-pinene $\left(k_{\mathrm{OH}+\beta \text {-pinene }}=7.43 \times 10^{-11} \mathrm{~cm}^{3}\right.$ molecule $\left.\mathrm{m}^{-1} \mathrm{~s}^{-1}\right)$ and with cyclohexane $\left(k_{\mathrm{OH}}+\right.$ cyclohexane $=6.97 \times 10^{-12} \mathrm{~cm}^{3}$ molecule $^{-1}$ $\left.\mathrm{s}^{-1}\right) .^{63}$ Subsequently, based on the experimental design, known amounts of $\mathrm{NO}_{2}, \mathrm{SO}_{2}$, and/or $\mathrm{NH}_{3}$ stored in respective calibrated cylinders (490 ppm balanced in $\mathrm{N}_{2}$ for $\mathrm{NO}_{2}$ and $\mathrm{NH}_{3}, 973$ ppm balanced in $\mathrm{N}_{2}$ for $\mathrm{SO}_{2}$, YuyanGas, China) were added into the chamber by flow controllers. Then, the chamber was allowed to equilibrate for about $20 \mathrm{~min}$ before the addition of ozone that started the reaction (i.e., reaction time $=0 \mathrm{~min}$ ).

The second step was the particle formation and growth that lasted for about $3 \mathrm{~h}$ after the addition of $\mathrm{O}_{3}$. Particles were initially formed by homogeneous nucleation of products from $\beta$-pinene ozonolysis due to the lack of seed particles that would influence the particle composition. The initial amount of $\mathrm{O}_{3}$ was 3-4 times higher than that of $\beta$-pinene, so that $\beta$-pinene could be consumed to a negligible level, as measured by a gas chromatograph coupled with a flame ionization detector (7890B, Agilent Technologies, USA) with a DB-624 capillary column (30 m $\times 0.32 \mathrm{~mm}, 1.8 \mathrm{~mm}$ film thickness) when particle sampling started. During this period, particle size distribution, volume, and number concentrations were monitored continually by a scanning mobility particle sizer with a differential mobility analyzer (Model 3082, TSI Inc., USA) and a condensation particle counter (Model 3776, TSI Inc., USA). The mixing ratios of $\mathrm{NO}_{2}$ and $\mathrm{SO}_{2}$ were monitored by a $\mathrm{NO}-\mathrm{NO}_{2}-\mathrm{NO}_{x}$ analyzer (model $42 \mathrm{i}$, Thermo Scientific, USA) and $\mathrm{SO}_{2}$ analyzer (model 43i, Thermo Scientific, USA), respectively. The concentration of $\mathrm{NH}_{3}$ was not monitored and its initial concentration was obtained according to the volume of the chamber and its added amount. When the aerosol mass concentration stopped increasing, the experiment entered the third step where the generated aerosol particles were collected onto aluminum foil pieces by a 13-stage Dekati low-pressure impactor (DLPI+, DeKati Ltd, Finland) for offline chemical analysis. More detailed information about the particle measurement and sampling is provided in the Supporting Information.
2.2. Aerosol Yield Calculation and Correction. Aerosol yield $(Y)$ is defined as the aerosol particle mass change $(\Delta M$, $\left.\mu \mathrm{g} \mathrm{m}^{-3}\right)$ relative to the consumption of $\beta$-pinene $(\Delta[\beta$ pinene $\left.], \mu \mathrm{g} \mathrm{m}^{-3}\right): Y=\Delta M / \Delta[\beta$-pinene $]$. Aerosol particle mass concentrations were calculated based on the volume concentration measured by a scanning mobility particle sizer and the assumed $1.2 \mathrm{~g} \mathrm{~cm}^{-3}$ aerosol density. ${ }^{64}$ Inorganic salts formed during $\beta$-pinene ozonolysis would increase aerosol density, hereby underestimating the aerosol yield by less than $8 \%$ in $\mathrm{SO}_{2}$-involved experiments when the density of inorganic salts was assumed to be $1.58 \mathrm{~g} \mathrm{~cm}^{-3}$ (see the Supporting Information). ${ }^{65}$ The size-dependent wall loss rate of ammonium sulfate $\left(k_{\mathrm{dp}}=4.15 \times 10^{-7} \times D_{\mathrm{p}} 1.89+1.39 \times\right.$ $D_{\mathrm{p}}{ }^{-0.88}, D_{\mathrm{p}}$ is particle diameter in the unit of $\mathrm{nm}$ ) was applied to the correction of particle mass concentration. ${ }^{66}$ Details about this correction have been described in previous studies. ${ }^{34,67}$ Another factor that would influence the quantification of aerosol mass is the wall loss of organic vapors. ${ }^{68,69}$ Chamber walls and suspended particle surfaces compete for the deposition of organic vapors. ${ }^{70}$ Accelerating reaction rates by employing an excessive amount of oxidant was reported to be one efficient way to suppress organic vapor wall loss because the fast formed particles could provide a significant sink for organic vapors to partition. ${ }^{3653,71}$ The evaluation of the rate constants of vapor wall-loss and particleloss in our reaction system indicates that organic vapors condensed to particles much faster than to the chamber walls (details are given in the Supporting Information). Therefore, the organic vapor wall loss has a minor effect on the SOA yield calculation and comparison. $^{70,72}$

2.3. Chemical Composition Characterization. To get details about the functional group and chemical bond information of particle-forming compounds, particles collected onto aluminum foil pieces were analyzed by an attenuated total reflectance coupled to a Fourier transform infrared spectrometer (Vertex 70, Bruker, Germany). It was operated with a scan resolution of $4 \mathrm{~cm}^{-1}$ for the spectral range of $4000-600 \mathrm{~cm}^{-1}$. The spectra of blank aluminum foil pieces as backgrounds were subtracted from each sample measurement and the spectra baseline were corrected via the rubberband method (64 baseline points and 20 iterations).

Inorganic composition in secondary aerosol samples was further measured by means of ion chromatography (IC, Dionex ICS-600, Thermo Fisher, USA). Aluminum foil pieces were first dissolved in $4 \mathrm{~mL}$ of ultrapure water (Milli-Q Millipore, France), followed by sonication for $30 \mathrm{~min}$. Then, a Teflon membrane syringe filter $(25 \mathrm{~mm}$ diameter, $0.22 \mu \mathrm{m}$ pore, Jinteng, China) was used to remove insoluble species. Inorganic sulfate and ammonium in the prepared solution were measured with a Dionex IonPac CS12A analytical column $(4 \times$ $250 \mathrm{~mm})$ and Dionex IonPac AS19 analytical column $(4 \times 250$ $\mathrm{mm})$ associated with their guard-column $(4 \times 50 \mathrm{~mm})$, respectively. The eluents were potassium hydroxide and methanesulfonic acid solutions, with a flow rate of $1.0 \mathrm{~mL}$ $\mathrm{min}^{-1}$ for the separation of anions and cations, respectively.

To further characterize the aerosol organic composition, aerosol samples formed under different conditions (Table S1) were prepared and analyzed by ultraperformance liquid chromatography (UPLC, Ultimate 3000, Thermo scientific, USA)/electrospray ionization Q-Exactive-Focus high-resolution mass spectrometry (ESI-Q-Exactive-Focus HRMS, Thermo Scientific, USA). Organic compounds in sample extracts (sample extraction procedures are provided in the 

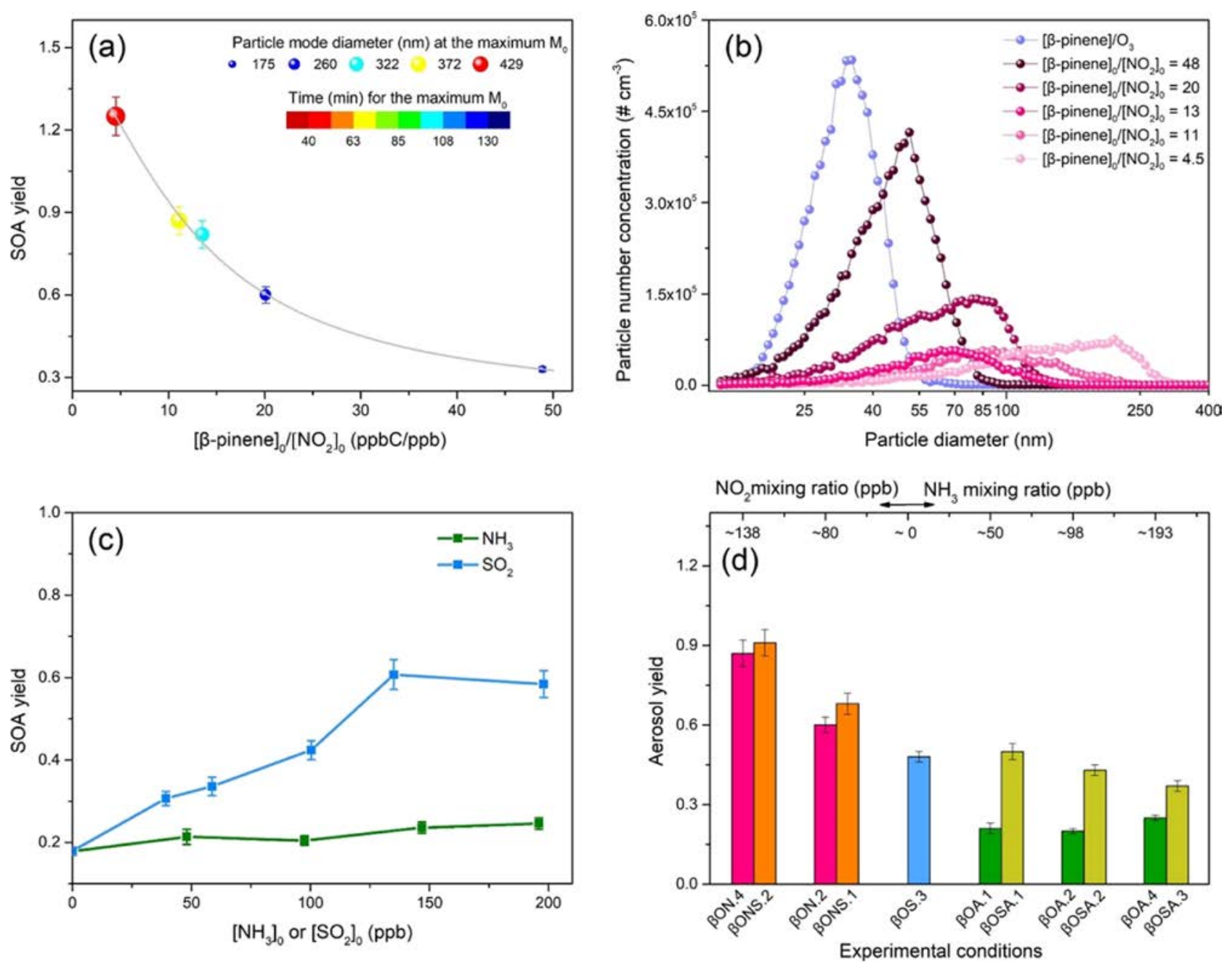

Figure 1. (a) SOA yield, particle mode diameter, and reaction time at the maximal SOA mass concentration $\left(M_{0}\right)$ as a function of the $[\beta \text {-pinene }]_{0} /$ $\left[\mathrm{NO}_{2}\right]_{0}$ ratios. (b) Particle size distribution in the first $5 \mathrm{~min}$ of reactions with different $[\beta \text {-pinene }]_{0} /\left[\mathrm{NO}_{2}\right]_{0}$ ratios. (c) SOA yield as a function of the initial mixing ratios of $\mathrm{SO}_{2}\left(\left[\mathrm{SO}_{2}\right]_{0}\right)$ and $\mathrm{NH}_{3}\left(\left[\mathrm{NH}_{3}\right]_{0}\right),(\mathrm{d})$ Comparison of the yield of aerosol formed in the presence of a single pollutant or mixed pollutants $\left(\mathrm{NO}_{2}+\mathrm{SO}_{2}\right.$ and $\left.\mathrm{SO}_{2}+\mathrm{NH}_{3}\right)$. Experimental details are listed in Table 1.

Supporting Information) were separated using an Atlantis T3 C18 column ( $100 \AA$, $3 \mu \mathrm{m}$ particle size, $2.1 \mathrm{~mm} \times 150 \mathrm{~mm}$, Waters, USA). The mass spectrometer was operated in both negative and positive ionization modes with the mass range of $m / z 50-750$. Based on the full scan MS information, the most intense precursor ions were fragmented by a higher-energy collision-induced dissociation to get the MS/MS scan. The details about the chromatographic elution program and mass spectrometric parameters are described in the Supporting Information.

\section{RESULTS AND DISCUSSION}

3.1. $\mathrm{NO}_{2}, \mathrm{SO}_{2}$, and $\mathrm{NH}_{3}$ Influenced $\beta$-Pinene SOA Formation. Experiments $\beta \mathrm{ON} .1-5$ were designed to study the effects of initial $\mathrm{NO}_{2}$ mixing ratios $\left(\left[\mathrm{NO}_{2}\right]_{0}\right)$ on $\beta$-pinene SOA formation. As shown in Figure 1a, the decrease in $[\beta$ pinene $]_{0} /\left[\mathrm{NO}_{2}\right]_{0}(\mathrm{ppbC} / \mathrm{ppb})$ ratios not only increased the SOA yield but also reduced the time for reaching the maximal aerosol mass concentration. Indeed, the particle size increase was accelerated by $\mathrm{NO}_{2}$ after the onset of the reaction (Figure 1b). $\mathrm{RH}$ variation in these experiments may induce uncertainties in the particle growth and SOA yield, but the $\mathrm{NO}_{2}$ enhancements in SOA formation can still be observed when excluding one experiment ( $\beta$ ON.2) conducted under relatively high $\mathrm{RH}^{73,74}$ Though $\mathrm{NO}_{2}$ could perturb gas chemistry via its reaction with peroxy radicals, the thermally unstable peroxy nitrates are generally insignificant in SOA formation. ${ }^{75,76} \mathrm{NO}_{3}$ radicals, which could be quickly formed via $\mathrm{NO}_{2}+\mathrm{O}_{3}$ reaction, are more likely to explain such an enhancive $\mathrm{NO}_{2}$ effect on particle formation rate and final mass due to its 5 orders of magnitude higher reactivity with $\beta$-pinene and higher SOA formation potential compared with $\beta$-pinene ozonolysis. ${ }^{33,77-80}$

The enhanced $\beta$-pinene oxidation by $\mathrm{NO}_{3}$ at high $\left[\mathrm{NO}_{2}\right]_{0}$ and subsequent product (e.g., organic nitrates with low volatility) condensation and/or particle coagulation would grow particles to larger sizes. ${ }^{14,81,82}$ When the particle mass reached its maximum, as shown in Figure $1 \mathrm{~b}$, particle mode diameter $\left(D_{\mathrm{pm}}\right)$ was $109 \mathrm{~nm}$ with no $\mathrm{NO}_{2}$, while much larger particles were formed under higher $\left[\mathrm{NO}_{2}\right]_{0}$ conditions (e.g., $D_{\mathrm{pm}}=429 \mathrm{~nm}$ when $\left.[\beta \text {-pinene }]_{0} /\left[\mathrm{NO}_{2}\right]_{0}=4.5\right)$. The enhanced SOA yields and particle size explained by $\mathrm{NO}_{3}$ chemistry are supported by the results from previous studies, for which SOA yields of similar aerosol mass and $D_{\mathrm{pm}}$ in $\mathrm{NO}_{3}$ induced $\beta$-pinene oxidation $\left(Y=1.34, D_{\mathrm{pm}}=\sim 450 \mathrm{~nm}\right)$ are comparable to those observed here. ${ }^{14,83}$ The much higher $\beta$ - 
pinene SOA formation potential at high $\mathrm{NO}_{2}$ condition is consistent with model predictions in the area near Houston, where $\mathrm{NO}_{3}$ oxidation of $\beta$-pinene alone was suggested to be the second-largest $\mathrm{SOA}$ source. ${ }^{84}$ In many $\mathrm{NO}_{x}$-polluted regions, enhanced night time SOA formation via $\mathrm{NO}_{3}$ oxidation of monoterpenes has been demonstrated. ${ }^{16,18,19,26}$ Our results also suggest that $\beta$-pinene could be an important contributor to the enhanced SOA formation at night in these places with high anthropogenic $\mathrm{NO}_{x}$ emissions.

For $\beta$-pinene ozonolysis in experiments $\beta$ OS.1-5, higher particle volume and number concentration as well as SOA yield (calculated by subtracting inorganic sulfate from the total aerosol as described in the Supporting Information and Table $\mathrm{S} 2$ ) were observed when $\left[\mathrm{SO}_{2}\right]_{0}$ was high (Figures $1 \mathrm{c}$ and $\mathrm{S} 1$ ), in line with the previously reported role of $\mathrm{SO}_{2}$ in the ozonolysis of limonene and butyl vinyl ether. ${ }^{38,66}$ The enhancement effect of $\mathrm{SO}_{2}$ on $\mathrm{SOA}$ yield is smaller than that of $\mathrm{NO}_{2}$. For example, with similar initial $\beta$-pinene concentrations, the presence of $100 \mathrm{ppb} \mathrm{SO}_{2}$ increased the SOA yield by 0.24 while $78 \mathrm{ppb} \mathrm{NO}_{2}$ increased $\mathrm{SOA}$ yield by 0.42 . Different from the direct competition between $\mathrm{NO}_{3}$ and $\mathrm{O}_{3}$ for $\beta$-pinene caused by $\mathrm{NO}_{2}$, one way for $\mathrm{SO}_{2}$ to affect SOA formation is by reacting with stabilized Criegee intermediates ( $\mathrm{sCIs}$ ), forming $\mathrm{SO}_{3}$ and finally sulfuric acid that is generally known to contribute to new particle formation and acidcatalyzed SOA formation. ${ }^{85-87}$ The formation of sulfate was confirmed by IC measurements. It is worth noting that the reaction between $\mathrm{SO}_{2}$ and $\mathrm{O}_{3}$ can be ruled out as the loss rates of $\mathrm{SO}_{2}$ were comparable and negligible regardless of whether or not $\mathrm{O}_{3}$ was present. The consumption of $\mathrm{SO}_{2}$ increased with increasing $\left[\mathrm{SO}_{2}\right]_{0}$ but decreased with $\left[\mathrm{NO}_{2}\right]_{0}$ when $\mathrm{NO}_{2}$ was also added (Figure S2). This is expected because the consumption of $\beta$-pinene by $\mathrm{NO}_{3}$ that is derived from the $\mathrm{NO}_{2}+\mathrm{O}_{3}$ reaction would lead to less sCI formation via $\beta$ pinene ozonolysis. Additionally, using formic acid (10 ppm) as the sCI scavenger in an additional experiment with similar reactant conditions to those of the $\beta \mathrm{OS} .2$ experiment, the $\mathrm{SO}_{2}$ consumption was nearly half compared to that in the absence of formic acid. This evidence suggests that the reaction between sCIs and $\mathrm{SO}_{2}$ is an important sink of $\mathrm{SO}_{2}$, which has been proposed to be a significant source of atmospheric $\mathrm{H}_{2} \mathrm{SO}_{4}$, especially in forest regions. ${ }^{88-90}$

The increased $\mathrm{SO}_{2}$ consumption with increasing $\left[\mathrm{SO}_{2}\right]_{0}$ leads to a linear $\left(R^{2}=0.97\right)$ increase of the fraction of sulfate in enhanced aerosol mass (Figure S3). Considering that the hydrolysis of organosulfates during sample extraction may have a minor contribution to sulfate detected by IC, this fraction would be less than 0.4 when $\mathrm{SO}_{2}$ decay reached $80 \mathrm{ppb}$. This significant difference suggests that besides the direct contribution of nucleated sulfate, other $\mathrm{SO}_{2}$-induced channels, such as the role of condensed sulfuric acid as seeds for capturing more SOA-forming vapors into the particle phase, acid-catalyzed heterogeneous reactions might also contribute to the enhanced particle formation. ${ }^{25,91-93}$

SOA yields increased with $\mathrm{NH}_{3}$ but the degree was much weaker than those of $\mathrm{NO}_{2}$ and $\mathrm{SO}_{2}$ (Figure 1c). The largest enhancement in SOA yield was observed to be $39 \%$ when the initial $\mathrm{NH}_{3}$ mixing ratio approached $196 \mathrm{ppb}$. The maximal particle number concentration $\left(N_{\max }\right)$ and particle geometric mean diameter $\left(D_{g m, m a x}\right)$ were also higher with $\mathrm{NH}_{3}$ present (Figure S4d). These $\mathrm{NH}_{3}$ effects on particle formation have also been reported during $\alpha$-pinene and limonene ozonolysis. ${ }^{42-44}$ Ammonium salts of low volatility formed through the gas-phase reaction between $\mathrm{NH}_{3}$ and organic acids (e.g., pinic acid, pinonic acid, norpinic acid, and norpinonic acid) were suggested to account for the enhanced $\alpha$-pinene/limonene SOA. The yield of organic acids was reported to be $4.2-17.2 \%$ of $\beta$-pinene $+\mathrm{O}_{3}$ reactions and many of these organic acids can be produced during the $\alpha$-pinene ozonolysis through similar reaction pathways. ${ }^{94-96}$ The vapor pressure of products from the $\mathrm{NH}_{3}$ + organic acid reaction were reported to be orders of magnitude lower than those of the corresponding acids. ${ }^{97}$ Thus, it is expected that the acid-base reaction yielding condensable salts might be responsible for the enhanced $\beta$ pinene SOA formation in the presence of $\mathrm{NH}_{3}$.

3.2. Joint Effects of $\mathrm{NO}_{2}$ and $\mathrm{SO}_{2}$ on Secondary Aerosol Formation. As discussed above, the presence of $\mathrm{NO}_{2}$ tends to produce larger particles with lower number concentrations, while $\mathrm{SO}_{2}$ efficiently magnifies the particle number concentrations by forming relatively smaller particles. Mixed $\mathrm{NO}_{2}$ and $\mathrm{SO}_{2}$ seem to neutralize the single effect of $\mathrm{NO}_{2}$ and $\mathrm{SO}_{2}$ on particle formation, but $\mathrm{SO}_{2}$ appears to be more effective in modifying particle size and number development. In the $\beta$ ONS. 1 experiment with $\left[\mathrm{NO}_{2}\right]_{0}=78$ $\mathrm{ppb},\left[\mathrm{SO}_{2}\right]_{0}=104 \mathrm{ppb}$, the stabilized $D_{\mathrm{gm}, \max }$ at the end of the experiment was $67 \mathrm{~nm}$ lower than that in the $\beta$ ON.2 case $\left(\left[\mathrm{NO}_{2}\right]_{0}=78 \mathrm{ppb}\right)$ but only $15 \mathrm{~nm}$ larger than in $\beta$ OS.3 case $\left.\left(\left[\mathrm{SO}_{2}\right]_{0}=100 \mathrm{ppb}\right)\right)($ Figure $\mathrm{S} 4 \mathrm{~b}, \mathrm{c}, \mathrm{e})$. Compared to the $\beta \mathrm{ON}$ experiments, the presence of $\mathrm{SO}_{2}$ in the mixed $\mathrm{NO}_{2}+\mathrm{SO}_{2}$ cases compensated for the reduction of $\mathrm{N}_{\max }$ caused by $\mathrm{NO}_{2}$, making it at least 10 times higher in the latter than in the former case. Conversely, compared to the $\beta \mathrm{OS}$ experiments, the presence of $\mathrm{NO}_{2}$ reduced $N_{\max }$ by about 0.8 times.

Unlike the neutralizing effects of $\mathrm{NO}_{2}$ and $\mathrm{SO}_{2}$ on the progression of particle size and number concentration, the coexistence of $\mathrm{NO}_{2}$ and $\mathrm{SO}_{2}$ shows a synergetic effect on the aerosol yield. As shown in Figure 1d, aerosol yields in $\beta$ ONS experiments were higher than in the corresponding $\beta \mathrm{ON}$ or $\beta$ OS experiments. The addition of $\mathrm{NO}_{2}$, on the one hand, introduces $\mathrm{NO}_{3}$, which could efficiently oxidize $\beta$-pinene and enhance SOA mass production. On the other hand, $\mathrm{SO}_{2}$ consumption is reduced likely due to the suppressed sCI formation via $\beta$-pinene ozonolysis (Figure S2). However, certain amounts of $\mathrm{SO}_{2}$ could still be oxidized and it is already efficient in modifying particle size distribution and number concentration. Hence, $\mathrm{SO}_{2}$-related enhancive effects, such as promoting the generation of small particles that could act as condensation sinks and heterogeneous reactions may also assist the particle mass production, leading to a higher aerosol yield in $\beta$ ONS experiments than in $\beta \mathrm{ON}$ experiments.

3.3. Joint Effects of $\mathrm{SO}_{2}$ and $\mathrm{NH}_{3}$ on Secondary Aerosol Formation. To study the combined effects of $\mathrm{SO}_{2}$ and $\mathrm{NH}_{3}$ on aerosol particle formation, three experiments were performed with $\left[\mathrm{SO}_{2}\right]_{0}$ of about $110 \mathrm{ppb}$ but varying $\left[\mathrm{NH}_{3}\right]_{0}$ $(\beta \mathrm{OSA} .1-3)$. In these experiments, the increase of $\left[\mathrm{NH}_{3}\right]_{0}$ led to a slight decrease of aerosol yields (Figure 1d). Interestingly, the aerosol yield in $\beta$ OSA.1 $\left(\left[\mathrm{SO}_{2}\right]_{0}=103 \mathrm{ppb},\left[\mathrm{NH}_{3}\right]_{0}=49\right.$ $\mathrm{ppb})$ was a little higher than that of $\beta \mathrm{OS} .3\left(\left[\mathrm{SO}_{2}\right]_{0}=100\right.$ $\mathrm{ppb})$. However, when $\left[\mathrm{NH}_{3}\right]_{0}$ was elevated to $98 \mathrm{ppb}$ or 190 $\mathrm{ppb}$, the aerosol yields decreased and were lower than that in the $\beta$ OS. 3 experiment. The $\mathrm{SO}_{2}$ consumptions in these experiments had a minor difference (Figure S2), suggesting the unlikeliness of $\mathrm{NH}_{3}$ to directly change the fate of $\mathrm{SO}_{2}$. However, $\mathrm{NH}_{3}$ would be absorbed onto the generated particles and acid-base neutralization reaction would occur between $\mathrm{NH}_{3}$ and $\mathrm{H}_{2} \mathrm{SO}_{4}{ }^{49,98}$ The produced ammonium sulfate 
(Figure S5) that could offer surface layers for condensation is crucial to particle formation. ${ }^{49,50,99,100}$ However, acid-related heterogeneous processes, which contribute to about $70 \%$ of the enhanced particle mass in the $\beta$ OS. 3 reaction, may be suppressed due to the neutralization reaction induced by $\mathrm{NH}_{3}$. Both the aerosol $\mathrm{pH}$ value (ranging from -2.5 to 1.2 ) modeled using the Extended Aerosol Inorganics Model (EAIM model II, http://www.aim.env.uea.ac.uk/aim/aim.php) and the aerosol neutralization degree $(0.4-0.9)$ calculated as the molar ratio of ammonium to sulfate $\left(\left[\mathrm{NH}_{4}{ }^{+}\right] /(2 \times\right.$ $\left[\mathrm{SO}_{4}{ }^{2-}\right]$ ) increased with $\left[\mathrm{NH}_{3}\right]_{0}$ (see the Supporting Information). ${ }^{101,102}$ No clear correlation between liquid water contents calculated by E-AIM model II and initial $\mathrm{NH}_{3}$ mixing ratios or aerosol yields could be observed. Therefore, the promoting effects derived from ammonium sulfate may not be enough to compensate for the mitigated acid catalytic effect and finally lead to the reduced aerosol yields with the increase of $\left[\mathrm{NH}_{3}\right]_{0}$. It should be noted that ammonia depletion is not characterized by the appropriate instrument in the present study. Hence, more experiments are required to give deeper insights into the disturbed aerosol formation mechanism of $\beta$-pinene ozonolysis in the presence of both $\mathrm{NH}_{3}$ and $\mathrm{SO}_{2}$.

3.4. Composition Analysis. 3.4.1. Identification of Functional Groups. A typical set of infrared spectra of the particles formed under different conditions is shown in Figure 2 , and the spectral assignment is summarized in Table S3.

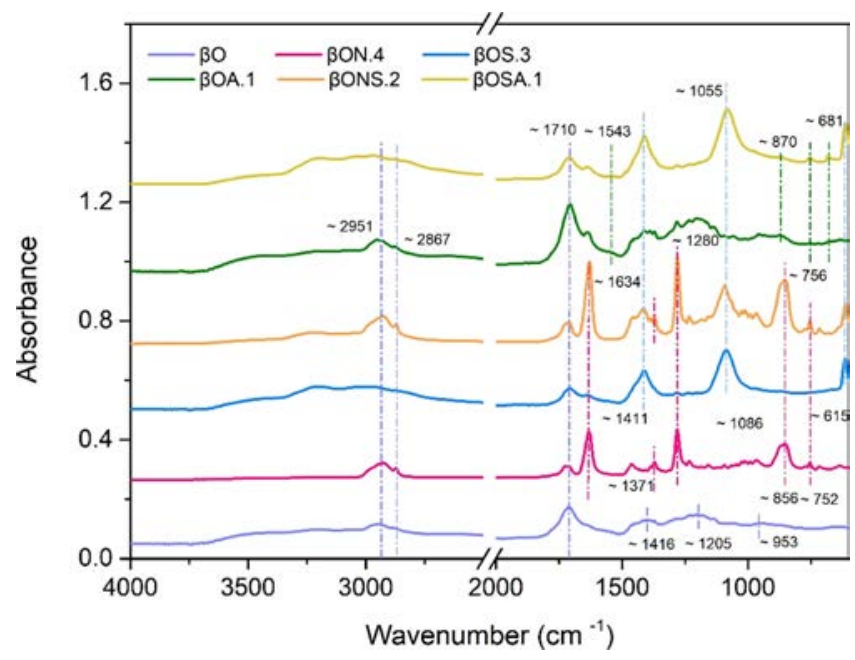

Figure 2. Infrared spectra of secondary aerosol particles generated from $\beta$-pinene ozonolysis under different experimental conditions. Experimental details are listed in Table 1.

When there were no inorganic gas pollutants present during $\beta$ pinene ozonolysis $(\beta \mathrm{O})$, the main absorption band peaks were observed at approximately $1710 \mathrm{~cm}^{-1}$, representing the stretching vibration of $\mathrm{C}=\mathrm{O}$ in carbonyl compounds. ${ }^{103,104}$ The absorbance in the 1490-1350, 1335-1105, and 990-820 $\mathrm{cm}^{-1}$ regions are the $\mathrm{C}-\mathrm{O}-\mathrm{H}$ in plane bending (and/or $\mathrm{C}-\mathrm{H}$ bending), $\mathrm{C}-\mathrm{O}$ stretching, and $\mathrm{O}-\mathrm{H}$ deformation vibrations (and/or carboxylic $\mathrm{C}-\mathrm{O}-\mathrm{H}$ out-of-plane bending), respectively. ${ }^{43,104-107}$ The broad bands range over 3680-3000 and $3000-2780 \mathrm{~cm}^{-1}$ are $\mathrm{O}-\mathrm{H}$ stretching in alcohols or acids and $\mathrm{C}-\mathrm{H}$ stretching absorption in the saturated carbon ring, respectively. ${ }^{105}$
When $\mathrm{NO}_{2}$ was added into $\beta$-pinene ozonolysis $(\beta \mathrm{ON}$ and $\beta$ ONS), the formation of organic nitrates can be evidenced by the strong absorption bands at $1634\left(\mathrm{NO}_{2}\right.$ asymmetric stretching), 1281 ( $\mathrm{NO}_{2}$ symmetric stretching), and $856 \mathrm{~cm}^{-1}$ (NO symmetric stretching). ${ }^{76,108}$ The weak peak at $752 \mathrm{~cm}^{-1}$ also corresponds to organic nitrates. ${ }^{7,109}$ The dominant $\mathrm{C}=\mathrm{O}$ absorption in the $\beta \mathrm{O}$ experiment is replaced by organic nitrates. The presence of $\mathrm{SO}_{2}$ induced new absorption bands located at 1412, 1086, and $615 \mathrm{~cm}^{-1}$, which represent characteristic absorption of $\mathrm{RO}-\mathrm{SO}_{2}-\mathrm{OR}^{\prime}$ in organosulfates, symmetric $\mathrm{S}-\mathrm{O}$ stretching in organic or inorganic sulfates, and the absorption of inorganic sulfate, respectively. ${ }^{110-112}$ Both characteristic absorption peaks of organic nitrates and sulfates can be observed in $\beta$ ONS experiments, consistent with $\mathrm{NO}_{3}$ chemistry and sCI-induced sulfate chemistry discussed above. For aerosol particles formed in the presence of $\mathrm{NH}_{3}$, very weak absorption peaks featuring at 870,756 , and $681 \mathrm{~cm}^{-1}$ (Figure S6) likely match the vibrations of the $-\mathrm{NH}_{2}$ group in the $\beta \mathrm{OA}$ experiment. ${ }^{106,113,114}$ The weaker IR absorption of nitrogencontaining species is somewhat in agreement with its slight SOA yield elevation, both of which indicate that $\mathrm{NH}_{3}$ likely has a minor effect on particle-forming product generation. The coexistence of $\mathrm{SO}_{2}$ and $\mathrm{NH}_{3}$ introduced both sulfur-containing and nitrogen-containing compounds and the absorptions at 681, 756, and $1543 \mathrm{~cm}^{-1}(\mathrm{~N}-\mathrm{H}$ bending and/or $\mathrm{C}-\mathrm{N}$ stretching) were enhanced, indicating that the joint effect of $\mathrm{SO}_{2}$ and $\mathrm{NH}_{3}$ may occur in the $\beta \mathrm{OSA}$ experiment.

3.4.2. Identification of Nitrogen- and Sulfur-Containing Organic Compounds. The main identified particle-phase products in the series have been summarized in Table S4 and Figure 3. For single $\beta$-pinene ozonolysis $(\beta \mathrm{O})$, a range of multifunctional products containing various combinations of carboxyl, carbonyl, and hydroxyl groups have been tentatively identified using high-resolution ESI $(+)$ and/or ESI $(-)$ mass spectrometry. ${ }^{94}$ As shown in Figure $\mathrm{S} 7, \beta$-pinene ozonolysis occurs via the formation of a cyclic primary ozonide, the cycloreversion of which produces a C9-Criegee intermediate with formaldehyde and a C1-Criegee intermediate with nopinone, with the former channel being much more favored than the latter. ${ }^{94,96,115,116}$ The unimolecular reaction of the C9Criegee intermediate via the hydroperoxide channel and the following series of radical reactions are responsible for the formation of the C8- and C9-monomers observed in the particle phase. In a previous study, organic acids, including pinic acid $(\mathrm{MW}=186)$, pinalic-3-acid $(\mathrm{MW}=170)$, and 4hydroxypinalic-3-acid ( $M W=186)$, have been observed in the early stage of $\beta$-pinene SOA growth. ${ }^{96}$ These condensed acids were tentatively identified in the present study and they could partially explain the initial particle growth after the onset of the reaction. ${ }^{96,117}$ Dimers form another important set of nucleating agents for SOA particle formation. ${ }^{118,119}$ Reactions of sCIs with carbonyls to form secondary ozonides or with carboxylic acid to form peroxide ester and reactions between hydroperoxide and carbonyls to form peroxyhemiacetals (Figure S7) could account for a portion of dimer formation observed in the particle phase. ${ }^{120,121}$

For aerosol particles generated from $\beta$-pinene ozonolysis in the presence of $\mathrm{NO}_{2}$, several organic nitrates were measured in positive ion mode as listed in Table S4. Their UPLC/QExactive-Focus HRMS extracted ion chromatograms (EICs) are shown in Figure S8. Four organic nitrates $\left[\mathrm{C}_{10} \mathrm{H}_{17} \mathrm{O}_{4} \mathrm{~N}\right.$ $(\mathrm{MW}=215), \mathrm{C}_{10} \mathrm{H}_{15} \mathrm{O}_{5} \mathrm{~N}(\mathrm{MW}=229), \mathrm{C}_{10} \mathrm{H}_{17} \mathrm{O}_{5} \mathrm{~N}(\mathrm{MW}=$ 231), $\left.\mathrm{C}_{10} \mathrm{H}_{15} \mathrm{O}_{6} \mathrm{~N}(\mathrm{MW}=245)\right]$ were identified, following the 


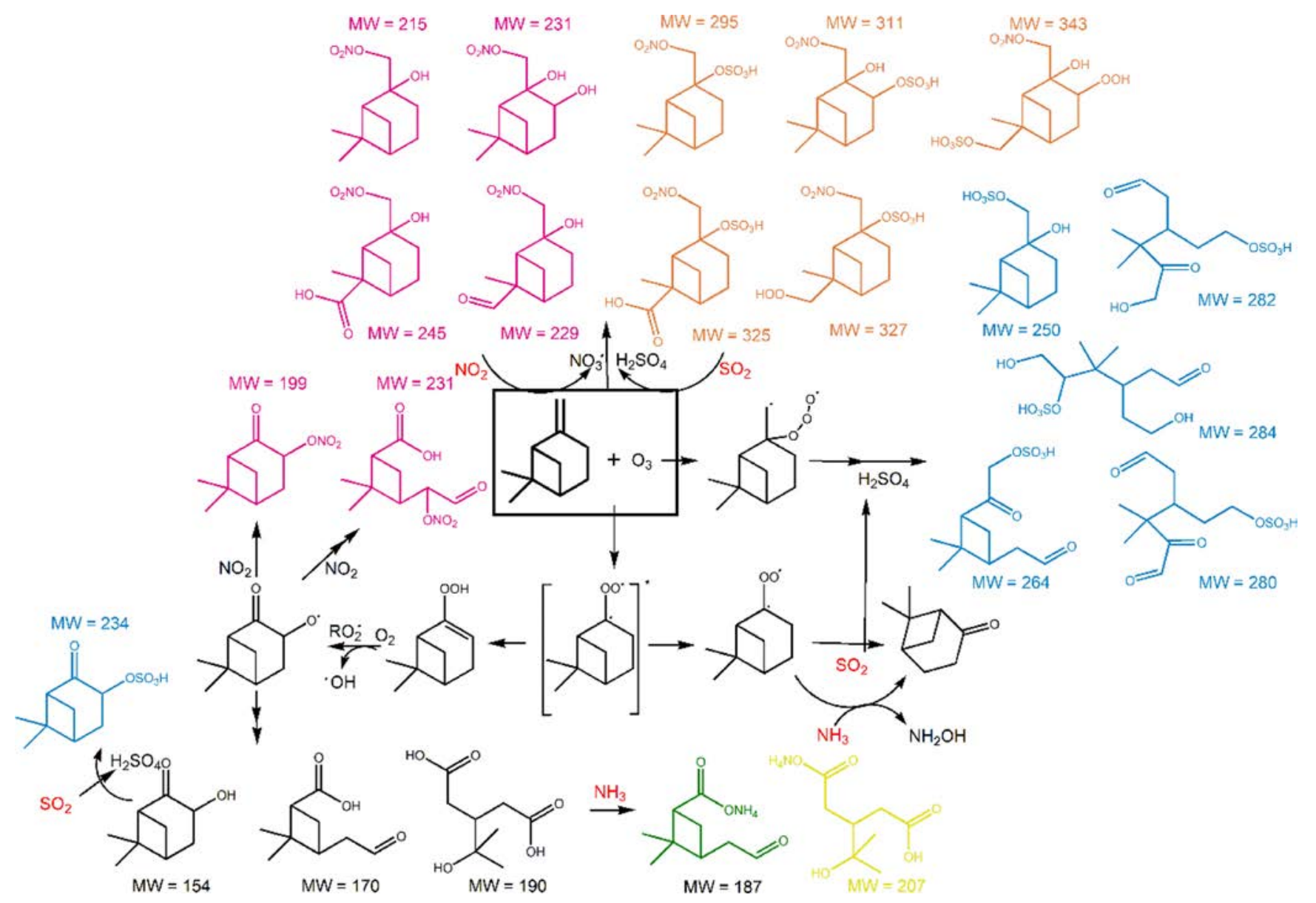

Figure 3. Summarized reaction scheme and products of $\beta$-pinene ozonolysis under different experimental conditions. For brevity, only one isomer of each compound is shown. Organic nitrates generated with the presence of $\mathrm{NO}_{2}$, organosulfates generated with the presence of $\mathrm{SO}_{2}$, nitrooxy organosulfates generated with the coexistence of $\mathrm{NO}_{2}$ and $\mathrm{SO}_{2}$, organic ammonium generated with the presence of $\mathrm{NH}_{3}$, and the coexistence of $\mathrm{SO}_{2}$ and $\mathrm{NH}_{3}$ are colored in pink, blue, orange, green, and yellow, respectively. Detailed potential formation mechanism for organic nitrates, organosulfates, and nitrooxy organosulfates are provided in Figures S9 and S11.

$\mathrm{NO}_{3}$ oxidation mechanisms proposed in the literature (Figure S9), ${ }^{14,122}$ consistent with our explanation that $\mathrm{NO}_{2}$ increases the efficiency of $\beta$-pinene SOA production via its transformation to $\mathrm{NO}_{3}$. C10 compounds including those with the following chemical formulas, that is, $\mathrm{C}_{10} \mathrm{H}_{17} \mathrm{O}_{4} \mathrm{~N}, \mathrm{C}_{10} \mathrm{H}_{15} \mathrm{O}_{5} \mathrm{~N}$, and $\mathrm{C}_{10} \mathrm{H}_{17} \mathrm{O}_{5} \mathrm{~N}$, have been observed in many ambient aerosol samples. ${ }^{20,56,57,123}$ Field observations showed that they account for more particle mass during night time than during daytime. $^{20,22,56}$ The appearance of $\mathrm{C} 10$ organic nitrates in SOA samples produced under $\beta \mathrm{ON}$ conditions illustrates that night time $\beta$-pinene oxidation can be one of their potential sources. Two $\mathrm{C} 9$ organic nitrates $\left(\mathrm{C}_{9} \mathrm{H}_{14} \mathrm{O}_{4} \mathrm{~N}\right.$ with $\mathrm{MW}=199$ and $\mathrm{C}_{9} \mathrm{H}_{13} \mathrm{O}_{6} \mathrm{~N}$ with $\mathrm{MW}=231$ ) were also detected in positive ion mode. They might be produced via the reaction between $\mathrm{NO}_{2}$ and reactive intermediates such as alkoxy radicals since $\mathrm{NO}_{2}$ mixing ratios on the order of about $40 \mathrm{ppb}$ were still present in the reaction mixture at the end of this experiment. $^{124,125}$

$\beta$-Pinene has been evidenced to be an important organosulfate precursor from both field and laboratory investigations. $^{25,26,29,58,126}$ Acidic seed conditions are usually needed to transform $\beta$-pinene oxidation products to organosulfates through heterogeneous reactions. ${ }^{25,37,58,127}$ Though there were no acid seed particles added directly in the chamber during $\beta$-pinene ozonolysis, sulfuric acid produced via the reaction of sCIs with $\mathrm{SO}_{2}$ potentially created acidic conditions for some heterogeneous reactions. Organosulfates in aerosol particles from the $\beta$ OS experiment were identified based on their exact masses (i.e., $\Delta M / M$ within $\pm 5 \mathrm{ppm}$ ) and the characteristic fragments of the sulfate group, including $\mathrm{HSO}_{4}{ }^{-}$ $(m / z 97),{ }^{\bullet} \mathrm{OSO}_{3}{ }^{-}(m / z 96), \mathrm{HSO}_{3}{ }^{-}(\mathrm{m} / z 81)$, and ${ }^{\bullet} \mathrm{SO}_{3}{ }^{-}(\mathrm{m} /$ $z$ 80), were shown in the high-resolution tandem MS/MS spectra. The EICs and MS/MS spectra for these organosulfates are displayed in Figure S10. Organosulfates detected as $[\mathrm{M}-\mathrm{H}]^{-}$ ions with $\mathrm{m} / z 249,263$, and 283 were identified to be $\mathrm{C}_{10} \mathrm{H}_{17} \mathrm{O}_{5} \mathrm{~S}^{-}, \mathrm{C}_{10} \mathrm{H}_{15} \mathrm{O}_{6} \mathrm{~S}^{-}$, and $\mathrm{C}_{10} \mathrm{H}_{19} \mathrm{O}_{7} \mathrm{~S}^{-}$, respectively, consistent with those detected in particles generated from $\beta$ pinene ozonolysis in the presence of acidic sulfate seed particles. ${ }^{37,127}$ Ion formulas with $\mathrm{m} / z 279$ and 281 were assigned to $\mathrm{C}_{10} \mathrm{H}_{17} \mathrm{O}_{7} \mathrm{~S}^{-}$and $\mathrm{C}_{10} \mathrm{H}_{19} \mathrm{O}_{7} \mathrm{~S}^{-}$, respectively. They have been previously observed in aerosols generated from $\alpha$ pinene, limonene, and $\alpha$-terpinene oxidation and $\beta$-pinene photooxiation in the presence of acidic seeds. ${ }^{25,128}$ Indeed, all of these five organosulfates have a certain abundance in ambient particles collected from urban, forest, and marine regions in Asia, Europe, and the US. ${ }^{10,25,28,29,58,129}$ Our results demonstrate the potential contribution of $\beta$-pinene to these organosulfates, especially to $\mathrm{C}_{10} \mathrm{H}_{18} \mathrm{O}_{7} \mathrm{~S}$ and $\mathrm{C}_{10} \mathrm{H}_{20} \mathrm{O}_{7} \mathrm{~S}$ via the night time ozonolysis in the presence $\mathrm{SO}_{2}$. Besides the $\mathrm{C} 10$ organosulfates, two $\mathrm{C} 9$ compounds $(\mathrm{m} / z 233$ and $\mathrm{m} / z$ 249) 

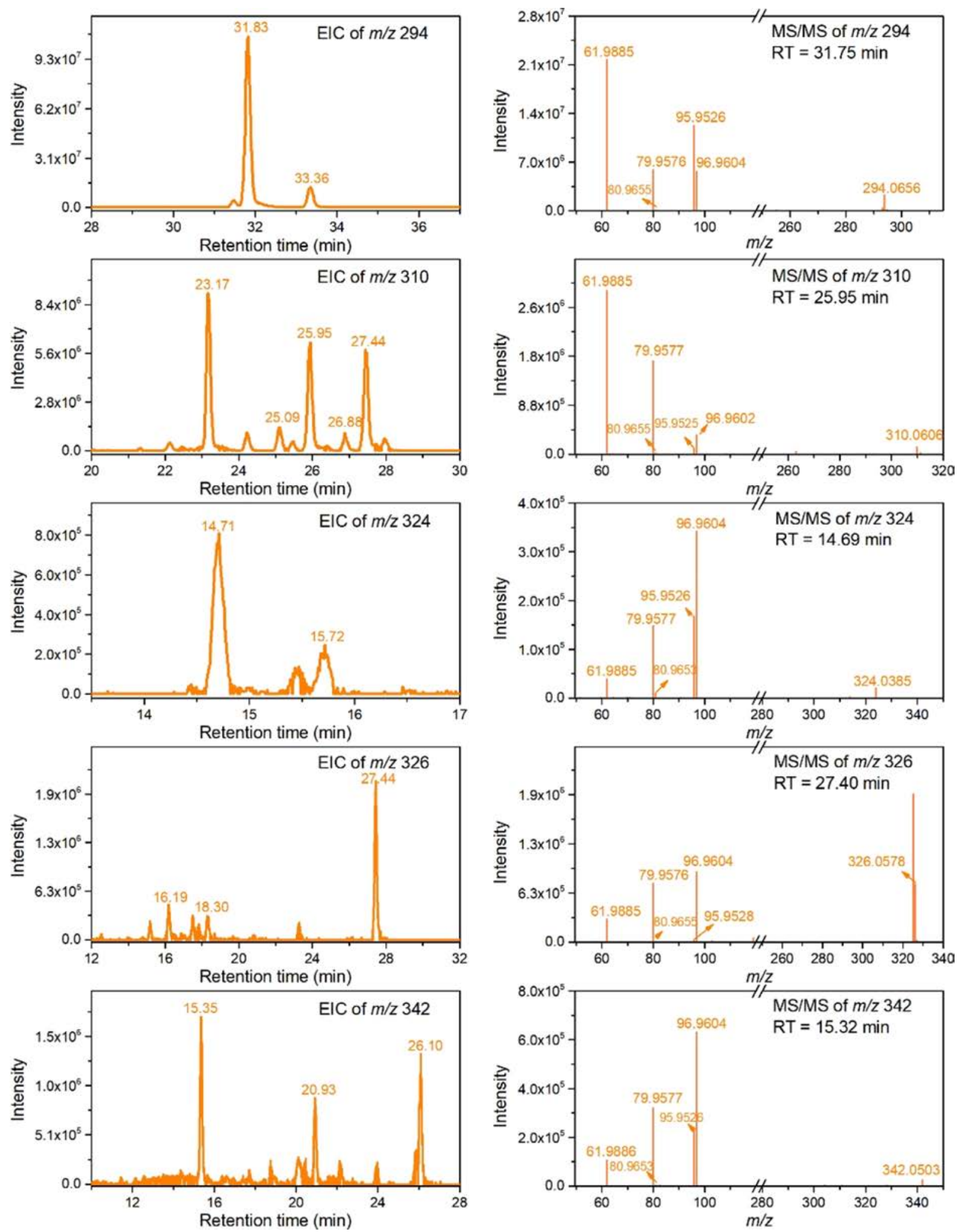

Figure 4. UPLC/Q-Exactive-Focus HRMS EICs and MS/MS spectra for $m / z 294,310,324,326,342$ ions (negative ion mode) in secondary aerosols generated from $\beta$-pinene ozonolysis with the coexistence of $\mathrm{NO}_{2}$ and $\mathrm{SO}_{2}$ (experimental details are listed in Table $\mathrm{S} 2$ in the Supporting Information). The maximal tolerance of mass error for all the precursor ions and product ions was set at $5 \mathrm{ppm}$.

were tentatively identified to organosulfates $\left(\mathrm{C}_{9} \mathrm{H}_{13} \mathrm{O}_{5} \mathrm{~S}^{-}\right.$and $\mathrm{C}_{9} \mathrm{H}_{13} \mathrm{O}_{6} \mathrm{~S}^{-}$, Figure $\left.\mathrm{S} 10\right)$. While the reaction between sulfuric acid and 3-hydroxynopinone that is generated from the Criegee channel might explain the formation of the
$\mathrm{C}_{9} \mathrm{H}_{13} \mathrm{O}_{5} \mathrm{~S}^{-}$ion, the formation mechanism for $\mathrm{C}_{9} \mathrm{H}_{13} \mathrm{O}_{6} \mathrm{~S}^{-}$is still unknown and needs to be further investigated.

The formation of the $\mathrm{C} 10$ organosulfates suggests that some C10 precursors, which could not be produced via the Criegee mechanism that leads to the fracture of the $\mathrm{C} 10$ skeleton in $\beta$ - 
pinene to produce molecules containing less than nine carbons, should be produced through alternative reaction channels. ${ }^{29,37}$ As suggested in the literature, ozone tends to form an oxygen carbon $\sigma$-bond with one of the unsaturated carbon atoms of $\beta$ pinene (Figure S11). This $\sigma$-complex then undergoes decomposition, likely leading to a $\beta$-pinene oxide and myrtenol. While bicyclic organosulfates $(\mathrm{m} / z$ 249) are most likely formed through the direct attack of $\mathrm{HSO}_{4}{ }^{-}$on the protonated epoxide or its nucleophilic addition to the carbocation formed from the decomposition of protonated epoxide, a four-carbon ring-opened organosulfate $(\mathrm{m} / z$ 249) was also reported to derive from the rearranged carbocation. ${ }^{107,126,130,131}$ Myrtenol can be further oxidized by ozone and, after a series of reactions, finally produces some $\mathrm{C} 10$ compounds $\left(\mathrm{C}_{10} \mathrm{H}_{16} \mathrm{O}_{3}, \mathrm{C}_{10} \mathrm{H}_{16} \mathrm{O}_{4}, \mathrm{C}_{10} \mathrm{H}_{18} \mathrm{O}_{4}\right)$ containing the hydroxyl group. These $\mathrm{C} 10$ products can be detected in aerosol particles generated from the $\beta \mathrm{O}$ experiment in the absence of $\mathrm{SO}_{2}$ in the present study and in the literature. ${ }^{37}$ They possibly act as precursors for the formation of sulfate esters with $m / z 263,279,281,283$ via the esterification reaction of the alcohol group with sulfuric acid. ${ }^{25,92,126}$

When $\mathrm{NO}_{2}$ and $\mathrm{SO}_{2}$ were present during the reaction, five NOSs with $m / z 294,310,324,326$, and 342 in negative ion mode were characterized. In addition to the extract mass of the parent NOSs ions, the prominent fragment ions from the sulfate group and product ions of $\mathrm{NO}_{3}{ }^{-}(\mathrm{m} / z$ 62) from a nitrooxy group can be observed in their MS/MS spectra (Figure 4), confirming the coexistence of nitrooxy and sulfate groups in their structures. Consequently, the $[\mathrm{M}-\mathrm{H}]^{-}$ion formulas were $\mathrm{C}_{10} \mathrm{H}_{16} \mathrm{NO}_{7} \mathrm{~S}^{-}, \mathrm{C}_{10} \mathrm{H}_{16} \mathrm{NO}_{8} \mathrm{~S}^{-}, \mathrm{C}_{10} \mathrm{H}_{13} \mathrm{NO}_{9} \mathrm{~S}^{-}$, $\mathrm{C}_{10} \mathrm{H}_{15} \mathrm{NO}_{9} \mathrm{~S}^{-}$, and $\mathrm{C}_{10} \mathrm{H}_{16} \mathrm{NO}_{10} \mathrm{~S}^{-}$for $\mathrm{m} / z 294,310,324,326$, and 342 , respectively. Apart from the $m / z 324$ compound that is observed for the first time in the present study, other four NOS ions could also be formed from $\beta$-pinene photooxidation in the presence of acidic seed particles. ${ }^{25}$ With acidic seed particles, $\mathrm{NO}_{3}$-initiated $\alpha$-pinene oxidation was reported to produce NOSs ions at $\mathrm{m} / z 294$ and $310 .^{25}$ In the present study, with the absence of acidic seed particles, NOSs are proposed to be formed via the $\mathrm{NO}_{3}$-initiated $\beta$-pinene oxidation, followed by alcohol sulfate esterification reactions (Figure S9). These reaction pathways are expected because, as discussed above, $\mathrm{NO}_{2}$ and $\mathrm{SO}_{2}$ can influence the formation of $\mathrm{NO}_{3}$ and sulfuric acid. Not only these NOSs have been widely observed in ambient particles, but $m / z$ 294, 310, 326 NOSs generally have higher concentrations at night as observed in Shanghai and Beijing (China), California (US), Antwerp (Belgium), K-puszta (Hungary), northeastern Bavaria (German). ${ }^{10,17,26,28,29,58,132-134}$ Our results suggest that interactions between $\beta$-pinene, $\mathrm{O}_{3}, \mathrm{NO}_{2}$, and $\mathrm{SO}_{2}$ may enhance the formation of the five NOSs. Though the ratios of reactant concentrations used in the present study are comparable to that in the real atmosphere, whether or not these ambient NOSs could originate from $\beta$-pinene night time chemistry in addition to $\alpha$-pinene $\mathrm{NO}_{3}$-chemistry and monoterpene photooxidation in the presence of acidic sulfate particles should be further considered by a comprehensive analysis of specific atmospheric conditions. Future laboratory quantification of the yields of these nitrogen- and sulfur-containing products formed under typical atmospheric conditions is also needed to further illustrate their importance in the real atmosphere.

For $\mathrm{NH}_{3}$-involved $\beta$-pinene ozonolysis in the presence or absence of $\mathrm{SO}_{2}$, two organic ammonium carboxylates $\left(\mathrm{C}_{9} \mathrm{H}_{17} \mathrm{O}_{3} \mathrm{~N}\right.$ and $\left.\mathrm{C}_{8} \mathrm{H}_{17} \mathrm{O}_{5} \mathrm{~N}\right)$ were tentatively identified and their EICs are shown in Figure S12. These organic ammonium salts may be formed via the reaction between organic acids and $\mathrm{NH}_{3}$ in the gas-phase, followed by the partition to the particlephase, similar to the way of ammoniated product generation in $\mathrm{NH}_{3}$-involved $\alpha$-pinene ozonolysis and photooxidation. ${ }^{42,45}$

\section{ATMOSPHERIC IMPLICATION}

Currently, levels of $\mathrm{O}_{3}$ and $\mathrm{NH}_{3}$ in the atmosphere have been increasing over many regions of the earth. ${ }^{135,136}$ Though anthropogenic emissions of $\mathrm{SO}_{2}$ and $\mathrm{NO}_{2}$ have declined, their concentrations can still be above $100 \mathrm{ppb}$ during severe haze pollution episodes. ${ }^{137,138}$ Anthropogenic-biogenic interactions occurring between $\beta$-pinene and these pollutants have been systematically investigated in the present study for the first time. It is demonstrated that $\mathrm{NO}_{2}$ and $\mathrm{SO}_{2}$ efficiently enhanced SOA formation, while $\mathrm{NH}_{3}$ exhibited minor effects. The distinctly different responses of particle generation to mixed pollutants $\left(\mathrm{SO}_{2}+\mathrm{NO}_{2}\right.$ and $\left.\mathrm{SO}_{2}+\mathrm{NH}_{3}\right)$ from that to the single one suggest that considering only the separate impacts of these pollutants likely induces bias prediction of secondary aerosol production. The observations here may be important for the accurate prediction of aerosol formation potential in regions with both anthropogenic and biogenic influences. The detection of particulate organic nitrates, organosulfates, as well as nitrooxy organosulfates pointed to the reaction channel leading to their formation even without any additional acidic seed particles. The increase of $\mathrm{O}_{3}$ may further strengthen the importance of night time ozonolysis in the production of particulate nitrogen- and sulfur-containing compounds. These species have significant atmospheric impacts as organic nitrates could serve as permanent $\mathrm{NO}_{x}$ sinks to influence $\mathrm{NO}_{x}$ and $\mathrm{O}_{3}$ cycling and organosulfates might affect the hygroscopicity of aerosol particles and cloud condensation nuclei properties. ${ }^{4,19,126}$ Though the naturally emitted BVOCs cannot be controlled directly, our results show that a fraction of biogenic SOA, such as these nitrogen- and sulfur-containing organics, can be controlled by mitigating anthropogenic pollutants, particularly $\mathrm{NO}_{2}$ and $\mathrm{SO}_{2}$. Future research considering a better representation of chemically detailed anthropogenic-biogenic interactions in models is warranted to help to evaluate controllable SOA budget and reduce uncertainties in predicting the impacts of aerosol particles on air quality, climate, and human health.

\section{ASSOCIATED CONTENT}

\section{Supporting Information}

The Supporting Information is available free of charge at https://pubs.acs.org/doi/10.1021/acs.est.0c07879.

Additional experimental details; acidity calculation; assignment of ATR-FTIR absorption bands and compounds detected by UPLC/Q-Exactive-Focus HRMS; $\mathrm{SO}_{2}$ consumption and particle size distribution under different experimental conditions; IC measurement of aerosol-phase sulfate and ammonium; UPLC/ Q-Exactive-Focus HRMS EICs for organic nitrates, organosulfates, and organic ammonium; $\beta$-pinene ozonolysis and organic nitrates; and organosulfate formation mechanisms (PDF) 


\section{AUTHOR INFORMATION}

\section{Corresponding Author}

Lin Du - Environment Research Institute, Shandong University, Qingdao 266237, China; (1) orcid.org/00000001-8208-0558; Email: lindu@sdu.edu.cn

\section{Authors}

Li Xu - Environment Research Institute, Shandong University, Qingdao 266237, China; ○ orcid.org/0000-0003-05739296

Zhaomin Yang - Environment Research Institute, Shandong University, Qingdao 266237, China

Narcisse T. Tsona - Environment Research Institute, Shandong University, Qingdao 266237, China; 이이.org/ 0000-0002-6023-1850

Xinke Wang - Université Lyon, Université Claude Bernard Lyon 1, CNRS, IRCELYON, F-69626 Villeurbanne, France Christian George - School of Environmental Science and Engineering, Shandong University, Qingdao 266237, China; Université Lyon, Université Claude Bernard Lyon 1, CNRS, IRCELYON, F-69626 Villeurbanne, France; 이이.org/ 0000-0003-1578-7056

\section{Notes}

The authors declare no competing financial interest.

\section{ACKNOWLEDGMENTS}

This work was supported by the National Natural Science Foundation of China (91644214, 21876098), Youth Innovation Program of Universities in Shandong Province (2019KJD007), and Fundamental Research Fund of Shandong University (2020QNQT012). This project has received funding from the European Union's Horizon 2020 research and innovation program under grant agreement no 690958 .

\section{REFERENCES}

(1) Lelieveld, J.; Evans, J. S.; Fnais, M.; Giannadaki, D.; Pozzer, A. The contribution of outdoor air pollution sources to premature mortality on a global scale. Nature 2015, 525, 367-371.

(2) Jimenez, J. L.; Canagaratna, M. R.; Donahue, N. M.; Prevot, A. S. H.; Zhang, Q.; Kroll, J. H.; DeCarlo, P. F.; Allan, J. D.; Coe, H.; Ng, N. L.; Aiken, A. C.; Docherty, K. S.; Ulbrich, I. M.; Grieshop, A. P.; Robinson, A. L.; Duplissy, J.; Smith, J. D.; Wilson, K. R.; Lanz, V. A.; Hueglin, C.; Sun, Y. L.; Tian, J.; Laaksonen, A.; Raatikainen, T.; Rautiainen, J.; Vaattovaara, P.; Ehn, M.; Kulmala, M.; Tomlinson, J. M.; Collins, D. R.; Cubison, M. J.; Dunlea, J.; Huffman, J. A.; Onasch, T. B.; Alfarra, M. R.; Williams, P. I.; Bower, K.; Kondo, Y.; Schneider, J.; Drewnick, F.; Borrmann, S.; Weimer, S.; Demerjian, K.; Salcedo, D.; Cottrell, L.; Griffin, R.; Takami, A.; Miyoshi, T.; Hatakeyama, S.; Shimono, A.; Sun, J. Y.; Zhang, Y. M.; Dzepina, K.; Kimmel, J. R.; Sueper, D.; Jayne, J. T.; Herndon, S. C.; Trimborn, A. M.; Williams, L. R.; Wood, E. C.; Middlebrook, A. M.; Kolb, C. E.; Baltensperger, U.; Worsnop, D. R. Evolution of organic aerosols in the atmosphere. Science 2009, 326, 1525-1529.

(3) Dzepina, K.; Volkamer, R. M.; Madronich, S.; Tulet, P.; Ulbrich, I. M.; Zhang, Q.; Cappa, C. D.; Ziemann, P. J.; Jimenez, J. L. Evaluation of recently-proposed secondary organic aerosol models for a case study in Mexico City. Atmos. Chem. Phys. 2009, 9, 5681-5709.

(4) Nah, T.; Sanchez, J.; Boyd, C. M.; Ng, N. L. Photochemical Aging of $\alpha$-pinene and $\beta$-pinene Secondary Organic Aerosol formed from Nitrate Radical Oxidation. Environ. Sci. Technol. 2016, 50, 222231.
(5) Kanakidou, M.; Seinfeld, J. H.; Pandis, S. N.; Barnes, I.; Dentener, F. J.; Facchini, M. C.; Van Dingenen, R.; Ervens, B.; Nenes, A.; Nielsen, C. J.; Swietlicki, E.; Putaud, J. P.; Balkanski, Y.; Fuzzi, S.; Horth, J.; Moortgat, G. K.; Winterhalter, R.; Myhre, C. E. L.; Tsigaridis, K.; Vignati, E.; Stephanou, E. G.; Wilson, J. Organic aerosol and global climate modelling: A review. Atmos. Chem. Phys. 2005, 5, 1053-1123.

(6) Guenther, A.; Hewitt, C. N.; Erickson, D.; Fall, R.; Geron, C.; Graedel, T.; Harley, P.; Klinger, L.; Lerdau, M.; McKay, W. A.; Pierce, T.; Scholes, B.; Steinbrecher, R.; Tallamraju, R.; Taylor, J.; Zimmerman, P. A global model of natural volatile organic compound emissions. J. Geophys. Res. Atmos. 1995, 100, 8873-8892.

(7) Guenther, A. B.; Jiang, X.; Heald, C. L.; Sakulyanontvittaya, T.; Duhl, T.; Emmons, L. K.; Wang, X. The Model of Emissions of Gases and Aerosols from Nature version 2.1 (MEGAN2.1): an extended and updated framework for modeling biogenic emissions. Geosci. Model Dev. 2012, 5, 1471-1492.

(8) Yee, L. D.; Isaacman-VanWertz, G.; Wernis, R. A.; Kreisberg, N. M.; Glasius, M.; Riva, M.; Surratt, J. D.; de Sá, S. S.; Alexander, M. L.; Palm, B. B.; Hu, W.; Campuzano-Jost, P.; Day, D. A.; Jimenez, J. L.; Liu, Y.; Misztal, P. K.; Artaxo, P.; Viegas, J.; Manzi, A.; de Souza, R. A. F.; Edgerton, E. S.; Baumann, K.; Goldstein, A. H.; Goldstein, A. H. Natural and anthropogenically influenced isoprene oxidation in southeastern United States and central Amazon. Environ. Sci. Technol. 2020, 54, 5980-5991.

(9) Zhang, Y.-Q.; Chen, D.-H.; Ding, X.; Li, J.; Zhang, T.; Wang, J.Q.; Cheng, Q.; Jiang, H.; Song, W.; Ou, Y.-B.; Ye, P.-L.; Zhang, G.; Wang, X.-M. Impact of anthropogenic emissions on biogenic secondary organic aerosol: Observation in the Pearl River Delta, southern China. Atmos. Chem. Phys. 2019, 19, 14403-14415.

(10) Hettiyadura, A. P. S.; Al-Naiema, I. M.; Hughes, D. D.; Fang, T.; Stone, E. A. Organosulfates in Atlanta, Georgia: Anthropogenic influences on biogenic secondary organic aerosol formation. Atmos. Chem. Phys. 2019, 19, 3191-3206.

(11) Shilling, J. E.; Zaveri, R. A.; Fast, J. D.; Kleinman, L.; Alexander, M. L.; Canagaratna, M. R.; Fortner, E.; Hubbe, J. M.; Jayne, J. T.; Sedlacek, A.; Setyan, A.; Springston, S.; Worsnop, D. R.; Zhang, Q. Enhanced SOA formation from mixed anthropogenic and biogenic emissions during the CARES campaign. Atmos. Chem. Phys. 2013, 13, 2091-2113.

(12) Hoyle, C. R.; Boy, M.; Donahue, N. M.; Fry, J. L.; Glasius, M.; Guenther, A.; Hallar, A. G.; Huff Hartz, K.; Petters, M. D.; Petäjä, T.; Rosenoern, T.; Sullivan, A. P. A review of the anthropogenic influence on biogenic secondary organic aerosol. Atmos. Chem. Phys. 2011, 11, $321-343$.

(13) Shrivastava, M.; Cappa, C. D.; Fan, J.; Goldstein, A. H.; Guenther, A. B.; Jimenez, J. L.; Kuang, C.; Laskin, A.; Martin, S. T.; Ng, N. L.; Petaja, T.; Pierce, J. R.; Rasch, P. J.; Roldin, P.; Seinfeld, J. H.; Shilling, J.; Smith, J. N.; Thornton, J. A.; Volkamer, R.; Wang, J.; Worsnop, D. R.; Zaveri, R. A.; Zelenyuk, A.; Zhang, Q. Recent advances in understanding secondary organic aerosol: Implications for global climate forcing. Rev. Geophys. 2017, 55, 509-559.

(14) Boyd, C. M.; Sanchez, J.; Xu, L.; Eugene, A. J.; Nah, T.; Tuet, W. Y.; Guzman, M. I.; Ng, N. L. Secondary organic aerosol formation from the $\beta$-pinene $+\mathrm{NO}_{3}$ system: effect of humidity and peroxy radical fate. Atmos. Chem. Phys. 2015, 15, 7497-7522.

(15) Nagori, J.; Janssen, R. H. H.; Fry, J. L.; Krol, M.; Jimenez, J. L.; $\mathrm{Hu}, \mathrm{W}$.; Vilà-Guerau de Arellano, J. Biogenic emissions and landatmosphere interactions as drivers of the daytime evolution of secondary organic aerosol in the southeastern US. Atmos. Chem. Phys. 2019, 19, 701-729.

(16) Xu, L.; Guo, H.; Boyd, C. M.; Klein, M.; Bougiatioti, A.; Cerully, K. M.; Hite, J. R.; Isaacman-VanWertz, G.; Kreisberg, N. M.; Knote, C.; Olson, K.; Koss, A.; Goldstein, A. H.; Hering, S. V.; de Gouw, J.; Baumann, K.; Lee, S.-H.; Nenes, A.; Weber, R. J.; Ng, N. L. Effects of anthropogenic emissions on aerosol formation from isoprene and monoterpenes in the southeastern United States. Proc. Natl. Acad. Sci. U.S.A. 2015, 112, 37-42. 
(17) Hettiyadura, A. P. S.; Jayarathne, T.; Baumann, K.; Goldstein, A. H.; de Gouw, J. A.; Koss, A.; Keutsch, F. N.; Skog, K.; Stone, E. A. Qualitative and quantitative analysis of atmospheric organosulfates in Centreville, Alabama. Atmos. Chem. Phys. 2017, 17, 1343-1359.

(18) Kiendler-Scharr, A.; Mensah, A. A.; Friese, E.; Topping, D.; Nemitz, E.; Prevot, A. S. H.; Äijälä, M.; Allan, J.; Canonaco, F.; Canagaratna, M.; Carbone, S.; Crippa, M.; Dall Osto, M.; Day, D. A.; De Carlo, P.; Di Marco, C. F.; Elbern, H.; Eriksson, A.; Freney, E.; Hao, L.; Herrmann, H.; Hildebrandt, L.; Hillamo, R.; Jimenez, J. L.; Laaksonen, A.; McFiggans, G.; Mohr, C.; O’Dowd, C.; Otjes, R.; Ovadnevaite, J.; Pandis, S. N.; Poulain, L.; Schlag, P.; Sellegri, K.; Swietlicki, E.; Tiitta, P.; Vermeulen, A.; Wahner, A.; Worsnop, D.; $\mathrm{Wu}, \mathrm{H} . \mathrm{C}$. Ubiquity of organic nitrates from nighttime chemistry in the European submicron aerosol. Geophys. Res. Lett. 2016, 43, 77357744.

(19) Pye, H. O. T.; Luecken, D. J.; Xu, L.; Boyd, C. M.; Ng, N. L.; Baker, K. R.; Ayres, B. R.; Bash, J. O.; Baumann, K.; Carter, W. P. L.; Edgerton, E.; Fry, J. L.; Hutzell, W. T.; Schwede, D. B.; Shepson, P. B. Modeling the current and future roles of particulate organic nitrates in the Southeastern United States. Environ. Sci. Technol. 2015, 49, 14195-14203.

(20) Huang, W.; Saathoff, H.; Shen, X.; Ramisetty, R.; Leisner, T.; Mohr, C. Chemical characterization of highly functionalized organonitrates contributing to night-time organic aerosol mass loadings and particle growth. Environ. Sci. Technol. 2019, 53, 1165-1174.

(21) Sobanski, N.; Thieser, J.; Schuladen, J.; Sauvage, C.; Song, W.; Williams, J.; Lelieveld, J.; Crowley, J. N. Day and night-time formation of organic nitrates at a forested mountain site in south-west Germany. Atmos. Chem. Phys. 2017, 17, 4115-4130.

(22) Yu, K.; Zhu, Q; Du, K.; Huang, X.-F. Characterization of nighttime formation of particulate organic nitrates based on highresolution aerosol mass spectrometry in an urban atmosphere in China. Atmos. Chem. Phys. 2019, 19, 5235-5249.

(23) Liu, J.; Russell, L. M.; Ruggeri, G.; Takahama, S.; Claflin, M. S.; Ziemann, P. J.; Pye, H. O. T.; Murphy, B. N.; Xu, L.; Ng, N. L.; McKinney, K. A.; Budisulistiorini, S. H.; Bertram, T. H.; Nenes, A.; Surratt, J. D. Regional similarities and $\mathrm{NO}_{x}$-related increases in biogenic secondary organic aerosol in summertime southeastern United States. J. Geophys. Res. Atmos. 2018, 123, 10620-10636.

(24) Wang, Y.; Hu, M.; Wang, Y.-C.; Li, X.; Fang, X.; Tang, R.; Lu, S.; Wu, Y.; Guo, S.; Wu, Z.; Hallquist, M.; Yu, J. Z. Comparative Study of Particulate Organosulfates in Contrasting Atmospheric Environments: Field Evidence for the Significant Influence of Anthropogenic Sulfate and $\mathrm{NO}_{x}$. Environ. Sci. Technol. Lett. 2020, 7, 787-794.

(25) Surratt, J. D.; Gómez-González, Y.; Chan, A. W. H.; Vermeylen, R.; Shahgholi, M.; Kleindienst, T. E.; Edney, E. O.; Offenberg, J. H.; Lewandowski, M.; Jaoui, M.; Maenhaut, W.; Claeys, M.; Flagan, R. C.; Seinfeld, J. H. Organosulfate formation in biogenic secondary organic aerosol. J. Phys. Chem. A 2008, 112, 8345-8378.

(26) Wang, Y.; Hu, M.; Guo, S.; Wang, Y.; Zheng, J.; Yang, Y.; Zhu, W.; Tang, R.; Li, X.; Liu, Y.; Le Breton, M.; Du, Z.; Shang, D.; Wu, Y.; Wu, Z.; Song, Y.; Lou, S.; Hallquist, M.; Yu, J. The secondary formation of organosulfates under interactions between biogenic emissions and anthropogenic pollutants in summer in Beijing. Atmos. Chem. Phys. 2018, 18, 10693-10713.

(27) He, Q.-F.; Ding, X.; Wang, X.-M.; Yu, J.-Z.; Fu, X.-X.; Liu, T.Y.; Zhang, Z.; Xue, J.; Chen, D.-H.; Zhong, L.-J.; Donahue, N. M. Organosulfates from pinene and isoprene over the Pearl River Delta, South China: seasonal variation and implication in formation mechanisms. Environ. Sci. Technol. 2014, 48, 9236-9245.

(28) Kristensen, K.; Glasius, M. Organosulfates and oxidation products from biogenic hydrocarbons in fine aerosols from a forest in North West Europe during spring. Atmos. Environ. 2011, 45, 45464556.

(29) Iinuma, Y.; Müller, C.; Berndt, T.; Böge, O.; Claeys, M.; Herrmann, H. Evidence for the Existence of Organosulfates from $\beta$ Pinene Ozonolysis in Ambient Secondary Organic Aerosol. Environ. Sci. Technol. 2007, 41, 6678-6683.
(30) Chen, X.; Wang, H.; Liu, Y.; Su, R.; Wang, H.; Lou, S.; Lu, K. Spatial characteristics of the nighttime oxidation capacity in the Yangtze River Delta, China. Atmos. Environ. 2019, 208, 150-157.

(31) Perraud, V.; Bruns, E. A.; Ezell, M. J.; Johnson, S. N.; Yu, Y.; Alexander, M. L.; Zelenyuk, A.; Imre, D.; Chang, W. L.; Dabdub, D.; Pankow, J. F.; Finlayson-Pitts, B. J. Nonequilibrium atmospheric secondary organic aerosol formation and growth. Proc. Natl. Acad. Sci. U.S.A. 2012, 109, 2836-2841.

(32) Presto, A. A.; Huff Hartz, K. E.; Donahue, N. M. Secondary organic aerosol production from terpene ozonolysis. 2. Effect of $\mathrm{NO}_{x}$ concentration. Environ. Sci. Technol. 2005, 39, 7046-7054.

(33) Draper, D. C.; Farmer, D. K.; Desyaterik, Y.; Fry, J. L. A qualitative comparison of secondary organic aerosol yields and composition from ozonolysis of monoterpenes at varying concentrations of $\mathrm{NO}_{2}$. Atmos. Chem. Phys. 2015, 15, 12267-12281.

(34) Xu, L.; Tsona, N. T.; You, B.; Zhang, Y.; Wang, S.; Yang, Z.; Xue, L.; Du, L. $\mathrm{NO}_{x}$ enhances secondary organic aerosol formation from nighttime $\gamma$-terpinene ozonolysis. Atmos. Environ. 2020, 225, 117375.

(35) Riva, M.; Budisulistiorini, S. H.; Zhang, Z.; Gold, A.; Surratt, J. D. Chemical characterization of secondary organic aerosol constituents from isoprene ozonolysis in the presence of acidic aerosol. Atmos. Environ. 2016, 130, 5-13.

(36) Nah, T.; McVay, R. C.; Zhang, X.; Boyd, C. M.; Seinfeld, J. H.; $\mathrm{Ng}, \mathrm{N}$. L. Influence of seed aerosol surface area and oxidation rate on vapor wall deposition and SOA mass yields: a case study with $\alpha$ pinene ozonolysis. Atmos. Chem. Phys. 2016, 16, 9361-9379.

(37) Inuma, Y.; Kahnt, A.; Mutzel, A.; Böge, O.; Herrmann, H. Ozone-driven secondary organic aerosol production chain. Environ. Sci. Technol. 2013, 47, 3639-3647.

(38) Ye, J.; Abbatt, J. P. D.; Chan, A. W. H. Novel pathway of $\mathrm{SO}_{2}$ oxidation in the atmosphere: Reactions with monoterpene ozonolysis intermediates and secondary organic aerosol. Atmos. Chem. Phys. 2018, 18, 5549-5565.

(39) Yao, L.; Ma, Y.; Wang, L.; Zheng, J.; Khalizov, A.; Chen, M.; Zhou, Y.; Qi, L.; Cui, F. Role of stabilized Criegee Intermediate in secondary organic aerosol formation from the ozonolysis of $\alpha$ cedrene. Atmos. Environ. 2014, 94, 448-457.

(40) Ye, X.; Ma, Z.; Zhang, J.; Du, H.; Chen, J.; Chen, H.; Yang, X.; Gao, W.; Geng, F. Important role of ammonia on haze formation in Shanghai. Environ. Res. Lett. 2011, 6, 024019.

(41) Wu, Y.; Gu, B.; Erisman, J. W.; Reis, S.; Fang, Y.; Lu, X.; Zhang, $\mathrm{X}$. PM2.5 pollution is substantially affected by ammonia emissions in China. Environ. Pollut. 2016, 218, 86-94.

(42) Na, K.; Song, C.; Switzer, C.; Cocker, D. R. Effect of Ammonia on Secondary Organic Aerosol Formation from $\alpha$-Pinene Ozonolysis in Dry and Humid Conditions. Environ. Sci. Technol. 2007, 41, 60966102 .

(43) Babar, Z. B.; Park, J.-H.; Lim, H.-J. Influence of $\mathrm{NH}_{3}$ on secondary organic aerosols from the ozonolysis and photooxidation of $\alpha$-pinene in a flow reactor. Atmos. Environ. 2017, 164, 71-84.

(44) Niu, X.; Ho, S. S. H.; Ho, K. F.; Huang, Y.; Cao, J.; Shen, Z.; Sun, J.; Wang, X.; Wang, Y.; Lee, S.; Huang, R. Indoor secondary organic aerosols formation from ozonolysis of monoterpene: An example of d-limonene with ammonia and potential impacts on pulmonary inflammations. Sci. Total Environ. 2017, 579, 212-220.

(45) Hao, L.; Kari, E.; Leskinen, A.; Worsnop, D. R.; Virtanen, A. Direct contribution of ammonia to $\alpha$-pinene secondary organic aerosol formation. Atmos. Chem. Phys. 2020, 20, 14393-14405.

(46) Lin, Y.-H.; Knipping, E. M.; Edgerton, E. S.; Shaw, S. L.; Surratt, J. D. Investigating the influences of $\mathrm{SO}_{2}$ and $\mathrm{NH}_{3}$ levels on isoprene-derived secondary organic aerosol formation using conditional sampling approaches. Atmos. Chem. Phys. 2013, 13, 8457-8470.

(47) Liu, M.; Huang, X.; Song, Y.; Tang, J.; Cao, J.; Zhang, X.; Zhang, Q.; Wang, S.; Xu, T.; Kang, L.; Cai, X.; Zhang, H.; Yang, F.; Wang, H.; Yu, J. Z.; Lau, A. K. H.; He, L.; Huang, X.; Duan, L.; Ding, A.; Xue, L.; Gao, J.; Liu, B.; Zhu, T. Ammonia emission control in China would mitigate haze pollution and nitrogen deposition, but worsen acid rain. Proc. Natl. Acad. Sci. U.S.A. 2019, 116, 7760-7765. 
(48) Qi, X.; Zhu, S.; Zhu, C.; Hu, J.; Lou, S.; Xu, L.; Dong, J.; Cheng, P. Smog chamber study of the effects of $\mathrm{NO}_{x}$ and $\mathrm{NH}_{3}$ on the formation of secondary organic aerosols and optical properties from photo-oxidation of toluene. Sci. Total Environ. 2020, 727, 138632.

(49) Jiang, X.; Lv, C.; You, B.; Liu, Z.; Wang, X.; Du, L. Joint impact of atmospheric $\mathrm{SO}_{2}$ and $\mathrm{NH}_{3}$ on the formation of nanoparticles from photo-oxidation of a typical biomass burning compound. Environ. Sci.: Nano 2020, 7, 2532-2545.

(50) Chen, T.; Liu, Y.; Ma, Q.; Chu, B.; Zhang, P.; Liu, C.; Liu, J.; $\mathrm{He}, \mathrm{H}$. Significant source of secondary aerosol: Formation from gasoline evaporative emissions in the presence of $\mathrm{SO}_{2}$ and $\mathrm{NH}_{3}$. Atmos. Chem. Phys. 2019, 19, 8063-8081.

(51) Chu, B.; Zhang, X.; Liu, Y.; He, H.; Sun, Y.; Jiang, J.; Li, J.; Hao, J. Synergetic formation of secondary inorganic and organic aerosol: effect of $\mathrm{SO}_{2}$ and $\mathrm{NH}_{3}$ on particle formation and growth. Atmos. Chem. Phys. 2016, 16, 14219-14230.

(52) Sindelarova, K.; Granier, C.; Bouarar, I.; Guenther, A.; Tilmes, S.; Stavrakou, T.; Müller, J.-F.; Kuhn, U.; Stefani, P.; Knorr, W. Global data set of biogenic VOC emissions calculated by the MEGAN model over the last 30 years. Atmos. Chem. Phys. 2014, 14, 9317-9341.

(53) Burkholder, J. B.; Baynard, T.; Ravishankara, A. R.; Lovejoy, E. R. Particle nucleation following the $\mathrm{O}_{3}$ and $\mathrm{OH}$ initiated oxidation of $\alpha$-pinene and $\beta$-pinene between 278 and $320 \mathrm{~K}$. J. Geophys. Res. Atmos. 2007, 112, D10216.

(54) Kammer, J.; Perraudin, E.; Flaud, P.-M.; Lamaud, E.; Bonnefond, J. M.; Villenave, E. Observation of nighttime new particle formation over the French Landes forest. Sci. Total Environ. 2018, 621, 1084-1092.

(55) Kammer, J.; Flaud, P.-M.; Chazeaubeny, A.; Ciuraru, R.; Le Menach, K.; Geneste, E.; Budzinski, H.; Bonnefond, J. M.; Lamaud, E.; Perraudin, E.; Villenave, E. Biogenic volatile organic compounds (BVOCs) reactivity related to new particle formation (NPF) over the Landes forest. Atmos. Res. 2020, 237, 104869.

(56) Lee, B. H.; Mohr, C.; Lopez-Hilfiker, F. D.; Lutz, A.; Hallquist, M.; Lee, L.; Romer, P.; Cohen, R. C.; Iyer, S.; Kurtén, T.; Hu, W.; Day, D. A.; Campuzano-Jost, P.; Jimenez, J. L.; Xu, L.; Ng, N. L.; Guo, H.; Weber, R. J.; Wild, R. J.; Brown, S. S.; Koss, A.; de Gouw, J.; Olson, K.; Goldstein, A. H.; Seco, R.; Kim, S.; McAvey, K.; Shepson, P. B.; Starn, T.; Baumann, K.; Edgerton, E. S.; Liu, J.; Shilling, J. E.; Miller, D. O.; Brune, W.; Schobesberger, S.; D’Ambro, E. L.; Thornton, J. A. Highly functionalized organic nitrates in the southeast United States: Contribution to secondary organic aerosol and reactive nitrogen budgets. Proc. Natl. Acad. Sci. U.S.A. 2016, 113, 1516-1521.

(57) Ayres, B. R.; Allen, H. M.; Draper, D. C.; Brown, S. S.; Wild, R. J.; Jimenez, J. L.; Day, D. A.; Campuzano-Jost, P.; Hu, W.; de Gouw, J.; Koss, A.; Cohen, R. C.; Duffey, K. C.; Romer, P.; Baumann, K.; Edgerton, E.; Takahama, S.; Thornton, J. A.; Lee, B. H.; LopezHilfiker, F. D.; Mohr, C.; Wennberg, P. O.; Nguyen, T. B.; Teng, A.; Goldstein, A. H.; Olson, K.; Fry, J. L. Organic nitrate aerosol formation via $\mathrm{NO}_{3}+$ biogenic volatile organic compounds in the southeastern United States. Atmos. Chem. Phys. 2015, 15, 1337713392.

(58) Ma, Y.; Xu, X.; Song, W.; Geng, F.; Wang, L. Seasonal and diurnal variations of particulate organosulfates in urban Shanghai, China. Atmos. Environ. 2014, 85, 152-160.

(59) Han, T.; Qiao, L.; Zhou, M.; Qu, Y.; Du, J.; Liu, X.; Lou, S.; Chen, C.; Wang, H.; Zhang, F.; Yu, Q.; Wu, Q. Chemical and optical properties of aerosols and their interrelationship in winter in the megacity Shanghai of China. J. Environ. Sci. 2015, 27, 59-69.

(60) Wang, J.; Li, J.; Ye, J.; Zhao, J.; Wu, Y.; Hu, J.; Liu, D.; Nie, D.; Shen, F.; Huang, X.; Huang, D. D.; Ji, D.; Sun, X.; Xu, W.; Guo, J.; Song, S.; Qin, Y.; Liu, P.; Turner, J. R.; Lee, H. C.; Hwang, S.; Liao, H.; Martin, S. T.; Zhang, Q.; Chen, M.; Sun, Y.; Ge, X.; Jacob, D. J. Fast sulfate formation from oxidation of $\mathrm{SO}_{2}$ by $\mathrm{NO}_{2}$ and $\mathrm{HONO}$ observed in Beijing haze. Nat. Commun. 2020, 11, 2844.

(61) Xu, L.; Suresh, S.; Guo, H.; Weber, R. J.; Ng, N. L. Aerosol characterization over the southeastern United States using highresolution aerosol mass spectrometry: spatial and seasonal variation of aerosol composition and sources with a focus on organic nitrates. Atmos. Chem. Phys. 2015, 15, 7307-7336.

(62) Edwards, P. M.; Aikin, K. C.; Dube, W. P.; Fry, J. L.; Gilman, J. B.; de Gouw, J. A.; Graus, M. G.; Hanisco, T. F.; Holloway, J.; Hübler, G.; Kaiser, J.; Keutsch, F. N.; Lerner, B. M.; Neuman, J. A.; Parrish, D. D.; Peischl, J.; Pollack, I. B.; Ravishankara, A. R.; Roberts, J. M.; Ryerson, T. B.; Trainer, M.; Veres, P. R.; Wolfe, G. M.; Warneke, C.; Brown, S. S. Transition from high- to low- $\mathrm{NO}_{x}$ control of night-time oxidation in the southeastern US. Nat. Geosci. 2017, 10, 490-495.

(63) Atkinson, R.; Arey, J. Atmospheric degradation of volatile organic compounds. Chem. Rev. 2003, 103, 4605-4638.

(64) Sarrafzadeh, M.; Wildt, J.; Pullinen, I.; Springer, M.; Kleist, E.; Tillmann, R.; Schmitt, S. H.; Wu, C.; Mentel, T. F.; Zhao, D.; Hastie, D. R.; Kiendler-Scharr, A. Impact of $\mathrm{NO}_{x}$ and $\mathrm{OH}$ on secondary organic aerosol formation from $\beta$-pinene photooxidation. Atmos. Chem. Phys. 2016, 16, 11237-11248.

(65) Heym, C. Fluorescence histochemistry of biogenic monoamines. Techniques in Neuroanatomical Research; Springer, 1981; pp $139-170$.

(66) Zhang, P.; Chen, T.; Liu, J.; Liu, C.; Ma, J.; Ma, Q.; Chu, B.; $\mathrm{He}, \mathrm{H}$. Impacts of $\mathrm{SO}_{2}$, relative humidity, and seed acidity on secondary organic aerosol formation in the ozonolysis of butyl vinyl ether. Environ. Sci. Technol. 2019, 53, 8845-8853.

(67) Takekawa, H.; Minoura, H.; Yamazaki, S. Temperature dependence of secondary organic aerosol formation by photooxidation of hydrocarbons. Atmos. Environ. 2003, 37, 3413-3424.

(68) Ye, P.; Ding, X.; Hakala, J.; Hofbauer, V.; Robinson, E. S.; Donahue, N. M. Vapor wall loss of semi-volatile organic compounds in a Teflon chamber. Aerosol Sci. Technol. 2016, 50, 822-834.

(69) Zhang, X.; Cappa, C. D.; Jathar, S. H.; McVay, R. C.; Ensberg, J. J.; Kleeman, M. J.; Seinfeld, J. H. Influence of vapor wall loss in laboratory chambers on yields of secondary organic aerosol. Proc. Natl. Acad. Sci. U.S.A. 2014, 111, 5802-5807.

(70) Zhang, X.; Schwantes, R. H.; McVay, R. C.; Lignell, H.; Coggon, M. M.; Flagan, R. C.; Seinfeld, J. H. Vapor wall deposition in Teflon chambers. Atmos. Chem. Phys. 2015, 15, 4197-4214.

(71) Stirnweis, L.; Marcolli, C.; Dommen, J.; Barmet, P.; Frege, C.; Platt, S. M.; Bruns, E. A.; Krapf, M.; Slowik, J. G.; Wolf, R.; Prévôt, A. S. H.; Baltensperger, U.; El-Haddad, I. Assessing the influence of $\mathrm{NO}_{x}$ concentrations and relative humidity on secondary organic aerosol yields from $\alpha$-pinene photo-oxidation through smog chamber experiments and modelling calculations. Atmos. Chem. Phys. 2017, 17, 5035-5061.

(72) Matsunaga, A.; Ziemann, P. J. Gas-wall partitioning of organic compounds in a Teflon film chamber and potential effects on reaction product and aerosol yield measurements. Aerosol Sci. Technol. 2010, 44, 881-892.

(73) Bonn, B.; Schuster, G.; Moortgat, G. K. Influence of water vapor on the process of new particle formation during monoterpene ozonolysis. J. Phys. Chem. A 2002, 106, 2869-2881.

(74) Seinfeld, J. H.; Erdakos, G. B.; Asher, W. E.; Pankow, J. F. Modeling the formation of secondary organic aerosol (SOA). 2. The predicted effects of relative humidity on aerosol formation in the $\alpha$ pinene-, $\beta$-pinene-, sabinene-, $\Delta^{3}$-carene-, and cyclohexene-ozone systems. Environ. Sci. Technol. 2001, 35, 1806-1817.

(75) Atkinson, R. Gas-phase tropospheric chemistry of organic compounds: A review. Atmos. Environ. 2007, 41, 200-240.

(76) Hallquist, M.; Wängberg, I.; Ljungström, E.; Barnes, I.; Becker, K.-H. Aerosol and product yields from $\mathrm{NO}_{3}$ radical-initiated oxidation of selected monoterpenes. Environ. Sci. Technol. 1999, 33, 553-559.

(77) Wang, H.; Chen, X.; Lu, K.; Hu, R.; Li, Z.; Wang, H.; Ma, X.; Yang, X.; Chen, S.; Dong, H.; Liu, Y.; Fang, X.; Zeng, L.; Hu, M.; Zhang, $\mathrm{Y} . \mathrm{NO}_{3}$ and $\mathrm{N}_{2} \mathrm{O}_{5}$ chemistry at a suburban site during the EXPLORE-YRD campaign in 2018. Atmos. Environ. 2020, 224, 117180.

(78) Atkinson, R.; Hasegawa, D.; Aschmann, S. M. Rate constants for the gas-phase reactions of O3with a series of monoterpenes and related compounds at $296 \pm 2 \mathrm{~K}$. Int. J. Chem. Kinet. 1990, 22, 871887. 
(79) Sander, S.; Abbatt, J.; Barker, J.; Burkholder, J.; Friedl, R.; Golden, D.; Huie, R.; Kolb, C.; Kurylo, M.; Moortgat, G. Chemical Kinetics and Photochemical Data for Use in Atmospheric Studies, Evaluation Number 17; JPL Publication, 2011; Vol. 10, pp 1-11.

(80) Griffin, R. J.; Cocker, D. R.; Flagan, R. C.; Seinfeld, J. H. Organic aerosol formation from the oxidation of biogenic hydrocarbons. J. Geophys. Res. Atmos. 1999, 104, 3555-3567.

(81) Coeur-Tourneur, C.; Tomas, A.; Guilloteau, A.; Henry, F.; Ledoux, F.; Visez, N.; Riffault, V.; Wenger, J. C.; Bedjanian, Y. Aerosol formation yields from the reaction of catechol with ozone. Atmos. Environ. 2009, 43, 2360-2365.

(82) Fry, J. L.; Draper, D. C.; Barsanti, K. C.; Smith, J. N.; Ortega, J.; Winkler, P. M.; Lawler, M. J.; Brown, S. S.; Edwards, P. M.; Cohen, R. C.; Lee, L. Secondary organic aerosol formation and organic nitrate yield from $\mathrm{NO}_{3}$ oxidation of biogenic hydrocarbons. Environ. Sci. Technol. 2014, 48, 11944-11953.

(83) Bonn, B.; Moortgat, G. K. New particle formation during $\alpha$ and $\beta$-pinene oxidation by $\mathrm{O}_{3}, \mathrm{OH}$ and $\mathrm{NO}_{3}$, and the influence of water vapour: particle size distribution studies. Atmos. Chem. Phys. 2002, 2, 183-196.

(84) Russell, M. Predicting secondary organic aerosol formation rates in southeast Texas. J. Geophys. Res. 2005, 110, D07S17.

(85) Sipilä, M.; Jokinen, T.; Berndt, T.; Richters, S.; Makkonen, R.; Donahue, N. M.; Mauldin III, R. L.; Kurtén, T.; Paasonen, P.; Sarnela, N.; Ehn, M.; Junninen, H.; Rissanen, M. P.; Thornton, J.; Stratmann, F.; Herrmann, H.; Worsnop, D. R.; Kulmala, M.; Kerminen, V.-M.; Petäjä, T. Reactivity of stabilized Criegee intermediates (sCIs) from isoprene and monoterpene ozonolysis toward $\mathrm{SO}_{2}$ and organic acids. Atmos. Chem. Phys. 2014, 14, 12143-12153.

(86) Jang, M.; Czoschke, N. M.; Lee, S.; Kamens, R. M. Heterogeneous atmospheric aerosol production by acid-catalyzed particle-phase reactions. Science 2002, 298, 814-817.

(87) Sipila, M.; Berndt, T.; Petaja, T.; Brus, D.; Vanhanen, J.; Stratmann, F.; Patokoski, J.; Mauldin, R. L., 3rd; Hyvarinen, A.-P.; Lihavainen, H.; Kulmala, M. The role of sulfuric acid in atmospheric nucleation. Science 2010, 327, 1243-1246.

(88) Mauldin, R. L., III; Berndt, T.; Sipilä, M.; Paasonen, P.; Petäjä, T.; Kim, S.; Kurtén, T.; Stratmann, F.; Kerminen, V.-M.; Kulmala, M. A new atmospherically relevant oxidant of sulphur dioxide. Nature 2012, 488, 193-196.

(89) Huang, H.-L.; Chao, W.; Lin, J. J.-M. Kinetics of a Criegee intermediate that would survive high humidity and may oxidize atmospheric $\mathrm{SO}_{2}$. Proc. Natl. Acad. Sci. U.S.A. 2015, 112, 1085710862 .

(90) Boy, M.; Mogensen, D.; Smolander, S.; Zhou, L.; Nieminen, T.; Paasonen, P.; Plass-Dülmer, C.; Sipilä, M.; Petäjä, T.; Mauldin, L.; Berresheim, H.; Kulmala, M. Oxidation of $\mathrm{SO}_{2}$ by stabilized Criegee intermediate $(\mathrm{sCI})$ radicals as a crucial source for atmospheric sulfuric acid concentrations. Atmos. Chem. Phys. 2013, 13, 3865-3879.

(91) Stangl, C. M.; Krasnomowitz, J. M.; Apsokardu, M. J.; Tiszenkel, L.; Ouyang, Q.; Lee, S.; Johnston, M. V. Sulfur dioxide modifies aerosol particle formation and growth by ozonolysis of monoterpenes and isoprene. J. Geophys. Res. Atmos. 2019, 124, 48004811.

(92) Iinuma, Y.; Müller, C.; Böge, O.; Gnauk, T.; Herrmann, H. The formation of organic sulfate esters in the limonene ozonolysis secondary organic aerosol (SOA) under acidic conditions. Atmos. Environ. 2007, 41, 5571-5583.

(93) Zhang, P.; Chen, T.; Liu, J.; Chu, B.; Ma, Q.; Ma, J.; He, H. Impacts of mixed gaseous and particulate pollutants on secondary particle formation during ozonolysis of butyl vinyl ether. Environ. Sci. Technol. 2020, 54, 3909-3919.

(94) Ma, Y.; Marston, G. Multifunctional acid formation from the gas-phase ozonolysis of $\beta$-pinene. Phys. Chem. Chem. Phys. 2008, 10, 6115-6126.

(95) Yu, J.; Cocker, D. R., III; Griffin, R. J.; Flagan, R. C.; Seinfeld, J. H. Gas-phase ozone oxidation of monoterpenes: Gaseous and particulate products. J. Atmos. Chem. 1999, 34, 207-258.
(96) Jaoui, M.; Kamens, R. M. Mass balance of gaseous and particulate products from $\beta$-pinene $/ \mathrm{O}_{3} /$ air in the absence of light and $\beta$-pinene $/ \mathrm{NO}_{x} /$ air in the presence of natural sunlight. J. Atmos. Chem. 2003, 45, 101-141.

(97) Paciga, A. L.; Riipinen, I.; Pandis, S. N. Effect of ammonia on the volatility of organic diacids. Environ. Sci. Technol. 2014, 48, 13769-13775.

(98) Liggio, J.; Li, S.-M.; Vlasenko, A.; Stroud, C.; Makar, P. Depression of ammonia uptake to sulfuric acid aerosols by competing uptake of ambient organic gases. Environ. Sci. Technol. 2011, 45, 2790-2796.

(99) Zhang, R.; Khalizov, A.; Wang, L.; Hu, M.; Xu, W. Nucleation and growth of nanoparticles in the atmosphere. Chem. Rev. 2012, 112, 1957-2011.

(100) Behera, S. N.; Sharma, M. Degradation of $\mathrm{SO}_{2}, \mathrm{NO}_{2}$ and $\mathrm{NH}_{3}$ leading to formation of secondary inorganic aerosols: An environmental chamber study. Atmos. Environ. 2011, 45, 4015-4024.

(101) Wexler, A. S.; Clegg, S. L. Atmospheric aerosol models for systems including the ions $\mathrm{H}^{+}, \mathrm{NH}_{4}^{+}, \mathrm{Na}^{+}, \mathrm{SO}_{4}^{2-}, \mathrm{NO}_{3}^{-}, \mathrm{Cl}^{-}, \mathrm{Br}^{-}$, and $\mathrm{H}_{2} \mathrm{O}$. J. Geophys. Res. Atmos. 2002, 107, ACH 14-1.

(102) Engelhart, G. J.; Hildebrandt, L.; Kostenidou, E.; Mihalopoulos, N.; Donahue, N. M.; Pandis, S. N. Water content of aged aerosol. Atmos. Chem. Phys. 2011, 11, 911-920.

(103) Sax, M.; Zenobi, R.; Baltensperger, U.; Kalberer, M. Time Resolved Infrared Spectroscopic Analysis of Aerosol Formed by Photo-Oxidation of 1,3,5-Trimethylbenzene and $\alpha$-Pinene. Aerosol Sci. Technol. 2007, 39, 822-830.

(104) Roberts, J. E.; Zeng, G.; Maron, M. K.; Mach, M.; Dwebi, I.; Liu, Y. Measuring heterogeneous reaction rates with ATR-FTIR spectroscopy to evaluate chemical fates in an atmospheric environment: A physical chemistry and environmental chemistry laboratory experiment. J. Chem. Educ. 2016, 93, 733-737.

(105) Jia, L.; Xu, Y. Different roles of water in secondary organic aerosol formation from toluene and isoprene. Atmos. Chem. Phys. 2018, 18, 8137-8154.

(106) Simons, W. W. Sadtler Handbook of Infrared Spectra; Sadtler Research Laboratories, 1978.

(107) Lal, V.; Khalizov, A. F.; Lin, Y.; Galvan, M. D.; Connell, B. T.; Zhang, R. Heterogeneous reactions of epoxides in acidic media. $J$. Phys. Chem. A 2012, 116, 6078-6090.

(108) Bruns, E. A.; Perraud, V.; Zelenyuk, A.; Ezell, M. J.; Johnson, S. N.; Yu, Y.; Imre, D.; Finlayson-Pitts, B. J.; Alexander, M. L. Comparison of FTIR and particle mass spectrometry for the measurement of particulate organic nitrates. Environ. Sci. Technol. 2010, 44, 1056-1061.

(109) Day, D. A.; Liu, S.; Russell, L. M.; Ziemann, P. J. Organonitrate group concentrations in submicron particles with high nitrate and organic fractions in coastal southern California. Atmos. Environ. 2010, 44, 1970-1979.

(110) Allen, D. T.; Palen, E. J.; Haimov, M. I.; Hering, S. V.; Young, J. R. Fourier Transform Infrared Spectroscopy of Aerosol Collected in a Low Pressure Impactor (LPI/FTIR): Method Development and Field Calibration. Aerosol Sci. Technol. 1994, 21, 325-342.

(111) Coury, C.; Dillner, A. M. A method to quantify organic functional groups and inorganic compounds in ambient aerosols using attenuated total reflectance FTIR spectroscopy and multivariate chemometric techniques. Atmos. Environ. 2008, 42, 5923-5932.

(112) Shen, P.; Zhang, H.; Zhang, S.; Fei, L. Fabrication of completely interface-engineered $\mathrm{Ni}(\mathrm{OH})_{2} / \mathrm{rGO}$ nanoarchitectures for high-performance asymmetric supercapacitors. Appl. Surf. Sci. 2018, $460,65-73$.

(113) Mohiuddin, K.; Strezov, V.; Nelson, P. F.; Evans, T. Bonding structure and mineral analysis of size resolved atmospheric particles nearby steelmaking industrial sites in Australia. Aerosol Air Qual. Res. 2016, 16, 1638-1650.

(114) Liu, Y.; Liggio, J.; Staebler, R.; Li, S.-M. Reactive uptake of ammonia to secondary organic aerosols: Kinetics of organonitrogen formation. Atmos. Chem. Phys. 2015, 15, 13569-13584. 
(115) Ahrens, J.; Carlsson, P. T. M.; Hertl, N.; Olzmann, M.; Pfeifle, M.; Wolf, J. L.; Zeuch, T. Infrared Detection of Criegee Intermediates Formed during the Ozonolysis of $\beta$-Pinene and Their Reactivity towards Sulfur Dioxide. Angew. Chem., Int. Ed. 2014, 53, 715-719.

(116) Carlsson, P. T. M.; Keunecke, C.; Krüger, B. C.; Maass, M.-C.; Zeuch, T. Sulfur dioxide oxidation induced mechanistic branching and particle formation during the ozonolysis of $\beta$-pinene and 2-butene. Phys. Chem. Chem. Phys. 2012, 14, 15637-15640.

(117) Jenkin, M. E. Modelling the formation and composition of secondary organic aerosol from $\alpha$ - and $\beta$-pinene ozonolysis using MCM v3. Atmos. Chem. Phys. 2004, 4, 1741-1757.

(118) Docherty, K. S.; Wu, W.; Lim, Y. B.; Ziemann, P. J. Contributions of organic peroxides to secondary aerosol formed from reactions of monoterpenes with $\mathrm{O}_{3}$. Environ. Sci. Technol. 2005, 39, 4049-4059.

(119) Heaton, K. J.; Dreyfus, M. A.; Wang, S.; Johnston, M. V. Oligomers in the early stage of biogenic secondary organic aerosol formation and growth. Environ. Sci. Technol. 2007, 41, 6129-6136.

(120) Mackenzie-Rae, F. A.; Wallis, H. J.; Rickard, A. R.; Pereira, K. L.; Saunders, S. M.; Wang, X.; Hamilton, J. F. Ozonolysis of $\alpha$ phellandrene - Part 2: Compositional analysis of secondary organic aerosol highlights the role of stabilised Criegee intermediates. Atmos. Chem. Phys. 2018, 18, 4673-4693.

(121) Zhao, Z.; Xu, Q.; Yang, X.; Zhang, H. Heterogeneous ozonolysis of endocyclic unsaturated organic aerosol proxies: Implications for Criegee intermediate dynamics and later-generation reactions. ACS Earth Space Chem. 2019, 3, 344-356.

(122) Ng, N. L.; Brown, S. S.; Archibald, A. T.; Atlas, E.; Cohen, R. C.; Crowley, J. N.; Day, D. A.; Donahue, N. M.; Fry, J. L.; Fuchs, H.; Griffin, R. J.; Guzman, M. I.; Herrmann, H.; Hodzic, A.; Iinuma, Y.; Jimenez, J. L.; Kiendler-Scharr, A.; Lee, B. H.; Luecken, D. J.; Mao, J.; McLaren, R.; Mutzel, A.; Osthoff, H. D.; Ouyang, B.; PicquetVarrault, B.; Platt, U.; Pye, H. O. T.; Rudich, Y.; Schwantes, R. H.; Shiraiwa, M.; Stutz, J.; Thornton, J. A.; Tilgner, A.; Williams, B. J.; Zaveri, R. A. Nitrate radicals and biogenic volatile organic compounds: oxidation, mechanisms, and organic aerosol. Atmos. Chem. Phys. 2017, 17, 2103-2162.

(123) Fisher, J. A.; Jacob, D. J.; Travis, K. R.; Kim, P. S.; Marais, E. A.; Chan Miller, C.; Yu, K.; Zhu, L.; Yantosca, R. M.; Sulprizio, M. P.; Mao, J.; Wennberg, P. O.; Crounse, J. D.; Teng, A. P.; Nguyen, T. B.; St Clair, J. M.; Cohen, R. C.; Romer, P.; Nault, B. A.; Wooldridge, P. J.; Jimenez, J. L.; Campuzano-Jost, P.; Day, D. A.; Hu, W.; Shepson, P. B.; Xiong, F.; Blake, D. R.; Goldstein, A. H.; Misztal, P. K.; Hanisco, T. F.; Wolfe, G. M.; Ryerson, T. B.; Wisthaler, A.; Mikoviny, T. Organic nitrate chemistry and its implications for nitrogen budgets in an isoprene- and monoterpene-rich atmosphere: constraints from aircraft $\left(\mathrm{SEAC}^{4} \mathrm{RS}\right)$ and ground-based (SOAS) observations in the Southeast US. Atmos. Chem. Phys. 2016, 16, 5969-5991.

(124) Spittler, M.; Barnes, I.; Bejan, I.; Brockmann, K. J.; Benter, T.; Wirtz, $\mathrm{K}$. Reactions of $\mathrm{NO}_{3}$ radicals with limonene and $\alpha$-pinene: Product and SOA formation. Atmos. Environ. 2006, 40, 116-127.

(125) Gong, H.; Matsunaga, A.; Ziemann, P. J. Products and mechanism of secondary organic aerosol formation from reactions of linear alkenes with $\mathrm{NO}_{3}$ radicals. J. Phys. Chem. A 2005, 109, 43124324.

(126) Brüggemann, M.; Xu, R.; Tilgner, A.; Kwong, K. C.; Mutzel, A.; Poon, H. Y.; Otto, T.; Schaefer, T.; Poulain, L.; Chan, M. N.; Herrmann, H. Organosulfates in ambient aerosol: State of knowledge and future research directions on formation, abundance, fate, and importance. Environ. Sci. Technol. 2020, 54, 3767-3782.

(127) Surratt, J. D.; Lewandowski, M.; Offenberg, J. H.; Jaoui, M.; Kleindienst, T. E.; Edney, E. O.; Seinfeld, J. H. Effect of acidity on secondary organic aerosol formation from isoprene. Environ. Sci. Technol. 2007, 41, 5363-5369.

(128) Altieri, K. E.; Turpin, B. J.; Seitzinger, S. P. Oligomers, organosulfates, and nitroxy organosulfates in rainwater identified by ultra-high resolution electrospray ionization FT-ICR mass spectrometry. Atmos. Chem. Phys. 2008, 9, 2533-2542.
(129) Stone, E. A.; Yang, L.; Yu, L. E.; Rupakheti, M. Characterization of organosulfates in atmospheric aerosols at Four Asian locations. Atmos. Environ. 2012, 47, 323-329.

(130) Iinuma, Y.; Böge, O.; Kahnt, A.; Herrmann, H. Laboratory chamber studies on the formation of organosulfates from reactive uptake of monoterpene oxides. Phys. Chem. Chem. Phys. 2009, 11, 7985-7997.

(131) Cortés, D. A.; Elrod, M. J. Kinetics of the Aqueous Phase Reactions of Atmospherically Relevant Monoterpene Epoxides. J. Phys. Chem. A 2017, 121, 9297-9305.

(132) Gómez-González, Y.; Wang, W.; Vermeylen, R.; Chi, X.; Neirynck, J.; Janssens, I. A.; Maenhaut, W.; Claeys, M. Chemical characterisation of atmospheric aerosols during a 2007 summer field campaign at Brasschaat, Belgium: Sources and source processes of biogenic secondary organic aerosol. Atmos. Chem. Phys. 2012, 12, $125-138$

(133) Worton, D. R.; Goldstein, A. H.; Farmer, D. K.; Docherty, K. S.; Jimenez, J. L.; Gilman, J. B.; Kuster, W. C.; de Gouw, J.; Williams, B. J.; Kreisberg, N. M.; Hering, S. V.; Bench, G.; McKay, M.; Kristensen, K.; Glasius, M.; Surratt, J. D.; Seinfeld, J. H. Origins and composition of fine atmospheric carbonaceous aerosol in the Sierra Nevada Mountains, California. Atmos. Chem. Phys. 2011, 11, 1021910241.

(134) Gómez-González, Y.; Surratt, J. D.; Cuyckens, F.; Szmigielski, R.; Vermeylen, R.; Jaoui, M.; Lewandowski, M.; Offenberg, J. H.; Kleindienst, T. E.; Edney, E. O.; Blockhuys, F.; Van Alsenoy, C.; Maenhaut, W.; Claeys, M. Characterization of organosulfates from the photooxidation of isoprene and unsaturated fatty acids in ambient aerosol using liquid chromatography/(-) electrospray ionization mass spectrometry. J. Mass Spectrom. 2008, 43, 371-382.

(135) Xu, X. Recent advances in studies of ozone pollution and impacts in China: A short review. Curr. Opin. Environ. Sci. Health 2021, 19, 100225.

(136) Warner, J. X.; Dickerson, R. R.; Wei, Z.; Strow, L. L.; Wang, Y.; Liang, Q. Increased atmospheric ammonia over the world's major agricultural areas detected from space. Geophys. Res. Lett. 2017, 44, $2875-2884$.

(137) Liu, X. G.; Li, J.; Qu, Y.; Han, T.; Hou, L.; Gu, J.; Chen, C.; Yang, Y.; Liu, X.; Yang, T.; Zhang, Y.; Tian, H.; Hu, M. Formation and evolution mechanism of regional haze: a case study in the megacity Beijing, China. Atmos. Chem. Phys. 2013, 13, 4501-4514.

(138) Li, H.; Zhang, Q.; Zhang, Q.; Chen, C.; Wang, L.; Wei, Z.; Zhou, S.; Parworth, C.; Zheng, B.; Canonaco, F.; Prévôt, A. S. H.; Chen, P.; Zhang, H.; Wallington, T. J.; He, K. Wintertime aerosol chemistry and haze evolution in an extremely polluted city of the North China Plain: significant contribution from coal and biomass combustion. Atmos. Chem. Phys. 2017, 17, 4751-4768. 